\title{
Liquidity Provision of Limit Order Trading in the Futures Market Under Bull and Bear Markets
}

\author{
Min-Hsien Chiang, Tsai-Yin Lin and Chin-Hsien Jerry Yu*
}

\begin{abstract}
This study investigates how limit orders affect liquidity in a purely order-driven futures market. Additionally, the possible asymmetric relationship between market depth and transitory volatility in bull and bear markets and the effect of institutional trading on liquidity provision behavior are examined as well. The empirical results demonstrate that subsequent market depth increases as transient volatility increases in bull markets. Market depth exhibits significantly positive relationship to subsequent transient volatility in bull markets. Additionally, although trading volume positively influences transient volatility in bull markets, no such relationship exists in bear markets. Liquidity provision decreases when institutional trading activity intensifies during bear markets. Thus, liquidity provision for limit orders differs between bull and bear markets.
\end{abstract}

Keywords: market depth, limit order, bull and bear markets, institutional trading, liquidity

\section{INTRODUCTION}

Issues related to the liquidity provision of limit orders in the market microstructure have received extensive attention in recent years and have been explored from various perspectives. Glosten (1994) developed an equilibrium model within a limit order market in which patient liquidity traders provide market liquidity by submitting limit orders while urgent traders, normally acting on private information, submit market orders for matching against limit orders. Liquidity traders suffer losses from trading against informed traders, but even so can achieve net gains by trading against other liquidity traders, which makes the limit order market function. Seppi (1997) investigated the submission strategy of investors faced with different costs in a market

\footnotetext{
${ }^{*}$ Min-Hsien Chiang is at the Institute of International Business, National Cheng Kung University, Taiwan. Tsai-Yin Lin is at the Department of Finance, National Kaohsiung First University of Science and Technology,

Taiwan. Chih-Hsien Jerry Yu is at the Merrick School of Business, University of Baltimore, US. They would like to thank, Andrew W. Stark (editor), and an anonymous referee for valuable comments and suggestions. All errors and omissions remain the authors' sole responsibility. (Paper received June 2006, revised version accepted August 2008, Online publication June 2009)
}

Address for correspondence: Tsai-Yin Lin, Department of Finance, National Kaohsiung First University of Science and Technology, 2 Jhuoyue Rd., Nanzih, Kaohsiung, Taiwan. e-mail: iann0719@ms29.hinet.net 
structure (similar to the NYSE) in which active traders submit market orders, value traders submit limit orders, a specialist clears the market and a trading crowd submits limit orders to establish the limit order book. Handa and Schwartz (1996) extended Glosten's (1994) model to consider investor choice between limit and market orders in an order-driven market. They suggested that an increase in short-term price volatility tends to attract more limit orders, since the gains from trading against liquidity traders could exceed the losses from trading against informed traders. In a dynamic game setting within which current order flows influence subsequent order flows, Parlour (1998) proposed that more limit orders are submitted when the probability of executing limit orders exceeds that of the market orders. Finally, Foucault (1999) examined equilibrium in an order-driven market and proposed that liquidity traders tend to submit more limit orders when asset volatility is higher, since they face a higher risk of being picked off by submitting market orders.

Previous empirical studies have shown that liquidity provision of limit orders is related to the price volatility caused by limit order submission. Biais et al. (1995) studied the order flow of a limit order book on the Paris Bourse, a purely orderdriven market without any designated market makers. They found that limit order traders trade more aggressively when competition between limit orders is intense. Using the trading data of Dow Jones Industrial stocks traded on the NYSE, Handa and Schwartz (1996) found that limit order flows can be influenced by the shortterm price volatility associated with a paucity of limit orders. When examining the liquidity provision of limit orders on the NYSE, Kavajecz (1999) revealed that limit order traders reduce the market depth to achieve two goals: avoiding the adverse selection problems related to information uncertainty and mitigating uncertainty during volatile trading periods. Extending the work of Kavajecz (1999), Chung et al. (1999) examined limit orders on the NYSE and found that limit orders increase as asset volatility and transaction volume increase. In analysis of another purely order-driven market, namely the Stock Exchange of Hong Kong (SEHK), Ahn et al. (2001) found that market depth increases following a rise in transient volatility. Additionally, the market depth of buy and sell orders is influenced by transient volatility arising from the buy and sell sides, respectively.

This paper attempts to extend the research of Ahn et al. (2001) to study the futures market. Market depth in the futures market and the use of trading order flow data have seldom been considered. Examples include a study by Bessembinder and Sequin (1993) investigating the market depth of eight futures contracts by analyzing daily open interest data and a study by Pirrong (1996) analyzing trading volume to infer Bund contract liquidity. The futures contract examined in this investigation involves the TAIEX futures, which is based on the Taiwan Stock Exchange Capitalization Weighted Stock Index (TAIEX). The TAIEX futures contract was the first futures contract traded on the Taiwan Futures Exchange (TAIFEX). The TAIFEX adopted a purely orderdriven market with a continuous trading structure and no designated market makers obliged to provide market liquidity on futures trading. ${ }^{1}$ All trades are routed through the Electronic Trading System (ETS). The daily average trading volume of the TAIEX futures contract increased from 3,653 contracts in 1999 to 26,163 contracts in 2003.

1 It is noted that the Taiwan Futures Exchange launched a market maker system on some inactive futures products on October 8, 2007, to boost trading activities on these inactive futures products. Still, the Taiwan Futures Exchange maintains a purely order-driven market system on the TAIEX futures contract. 
Thus, the TAIEX futures contract is the most active index futures contract traded on the Taiwan Futures Exchange (TAIFEX) since its establishment in 1998.

Additionally, the research framework of this study examined upward and downward trends. The empirical evidence of previous asset price studies indicates that capital markets exhibit asymmetric responses to these different trends. French et al. (1987) indicated that stock volatility may unexpectedly increase when stock returns are negative. Examining the volatility of S\&P composite portfolio returns from 1928 to 1987, Schwert (1989) reported that increased volatility had a stronger association with negative returns than with positive returns. Engle and $\mathrm{Ng}$ (1993), in a comparative study of several asymmetric volatility models, suggested that negative return shocks have a greater impact than positive return shocks. In addition, Koutmos (1998) found that negative returns generate higher volatility, and information regarding negative returns is reflected in market prices faster than that regarding positive returns. Consequently, determining whether the liquidity provision differs between bull and bear markets is worth further inquiry.

The possible impact of institutional trading on the relationship between transient volatility and market depth is examined in this study as well. The trading activity of institutional traders might have an influential effect on liquidity provision behavior in futures markets. Institutional investors are assumed to have information superior to that of individual investors, since institutional investors actively engage in inhouse analysis. Bessembinder and Seguin (1993) indicated that the effect of trading volume on futures return volatility might depend on trader types. Daigler and Wiley (1999) found that traders with much more precise information about order flow, such as clearing members and floor traders, reduce futures return volatility while individual investors often increase futures return volatility due to a lack of order flow information. Additionally, Wiley and Daigler (1998) discovered that the trading activity of individual investors correlates with that of investors with superior information. Thus, the futures trading activity of each investor type is reactive to that of other investor types. Therefore, liquidity provision behavior may be provoked by liquidity traders in reaction to institutional trading activity.

The empirical results regarding the influence of transient volatility on subsequent market depth demonstrate that the market depth of limit orders increases following a rise in transient volatility in the bull market, while the market depth of limit orders decreases following a rise in transient volatility in the bear market. Restated, the positive relationship between transient volatility and subsequent market depth proposed by Handa and Schwartz (1996) and confirmed in Ahn et al. (2001) in an analysis of the SEHK occurs in bull markets for TAIEX futures but not in bear markets. This asymmetric response of market depth to changes in transient volatility may be due to the fact that information asymmetry and the probability of losses to informed traders are higher in bear markets. Consequently, liquidity traders tend to trade more conservatively when the market is downwards. This study also finds that, under conditions of increased trading intensity, the quoted size of limit orders increases but the number of limit orders decreases. Therefore, liquidity traders tend to increase their quoted size if the higher trading intensity exhausts their submitted orders. Further, in bull markets, liquidity traders tend to submit limit orders on buy and sell sides due to increased transient volatility on the sell side, whereas in bear markets liquidity traders place more limit buy (sell) orders than market orders when the transient volatility increases on the buy (sell) side. 
In contrast with the findings of Handa and Schwartz (1996) and Ahn et al. (2001), the increased influx of limit orders does not significantly reduce the subsequent transient volatility. Additionally, this study also reveals a significant positive relationship between trading volume and transient volatility in bull markets. Consequently, distinguishing between bull and bear markets helps to elucidate the trading behavior of liquidity traders. As for the impact of institutional trading activity on liquidity provision behavior, increased institutional trading activity reduces the liquidity provision under higher transient volatility in bear markets, while order submission is more aggressive when institutional traders are less active. Hence, liquidity traders do not trade aggressively during bear markets and in trading days with higher institutional trading, since the chances of losing to informed institutional traders are much higher.

The remainder of this paper is organized as follows. Section 2 outlines the hypotheses of the paper and describes the market structure of the Taiwan Futures Exchange. Section 3 then describes the study data, empirical methodology and construction of variables. Subsequently, Section 4 outlines and discusses the empirical results of the study. Finally, Section 5 presents the conclusions.

\section{HYPOTHESES AND MARKET DESCRIPTION}

\section{(i) Hypotheses}

Handa and Schwartz (1996) developed a framework for analyzing investor choice between limit and market orders in a purely order-driven market. Following Glosten (1994), Handa and Schwartz (1996) designed a framework that incorporated two types of traders: patient traders, also known as liquidity traders, who submit limit orders and provide liquidity to the market, and urgent traders, who submit market orders for immediate execution. Liquidity traders gain when trading against other liquidity traders, but lose when trading against informed traders. Limit orders increase when short-run volatility increases. This phenomenon occurs because short-term volatility can result from temporary order imbalances due to a paucity of limit orders. Therefore, limit orders placed by liquidity traders are likely to be matched against limit orders placed by other liquidity traders when short-run volatility is higher. Foucault (1999) also indicated that, during high volatility, liquidity traders submit limit orders instead of market orders since liquidity traders face a higher risk of being picked off by informed traders. Thus, the following hypothesis is proposed:

$\mathrm{H}_{1}$ : Market depth increases (decreases) following an increase (a decrease) in short- term volatility.

Conversely, the increased influx of limit orders because of increased short-term volatility continues until short-run volatility is reduced by price reversion. Therefore, a reduction in short-run volatility leads to a decline in submission of limit orders. The following hypothesis is thus developed:

$\mathrm{H}_{2}$ : An increase (decrease) in market depth is followed by a decrease (an increase) in short-run volatility.

Asymmetric responses to bull and bear markets are well documented in the literature. Generally, negative returns generate more unexpected volatility than positive returns. (e.g., French et al., 1987; and Schwert, 1989) Accordingly, Engle and Ng (1993) 
demonstrated a news impact curve with an asymmetric pattern, in which negative return shocks increase predictable volatility more than positive return shocks. In an analysis of stock indices in nine countries, Koutmos (1998) found that markets reflect bad news faster than good news. This phenomenon occurs because investors are highly risk averse in a downward market. Thus, the volatility generated in declining markets is more permanent than that generated in increasing markets, meaning that transient volatility is more common in bull markets. The evidence of asymmetric reactions in bull and bear markets yields the following hypothesis:

$\mathrm{H}_{3}$ : The relationship between market depth and transient volatility is much stronger in bull markets than in bear markets.

Institutional traders are major players in securities markets. Stock price movements are disproportionately affected by the larger cumulative impact of orders submitted by institutional traders with superior information (Chakravarty, 2001). To test the proposal by Bessembinder and Seguin (1993) that trader types influence the effect of trading volume on futures return volatility, Daigler and Wiley (1999) found that better informed traders, such as clearing members and floor traders, reduce futures return volatility, while individual investors with little knowledge of order flow information increase futures return volatility. Wiley and Daigler (1998) showed that futures trading activity by less informed traders is a reactive trading behavior with relation to traders with better information. Therefore, institutional trading might influence liquidity provision in the futures market. Consequently, the following hypothesis is proposed:

$\mathrm{H}_{4}$ : Liquidity provision behavior of limit orders is significantly influenced by institutional
trading.

\section{(ii) The Taiwan Futures Market}

The first futures contract traded on the Taiwan Futures Exchange (TAIFEX) was an index futures in which the underlying asset was the Taiwan Stock Exchange Capitalization Weighted Stock Index (TAIEX) (hereafter, TAIEX futures). The TAIEX futures were launched on July 21, 1998, and were traded using the in-house designed Electronic Trading System (ETS) from 8:45 a.m. to 1:45 p.m. Other than during the opening and closing periods, the ETS features a continuous trading system in which submitted orders are matched first by price priority and then by time priority. ${ }^{2}$ The opening price is determined by orders submitted fifteen minutes before trading opens at 8:45 a.m. Orders then build up and are matched on a competitive auction basis via the ETS by price priority followed by time priority. The closing price is settled by the accumulated orders during one minute before 1:45 p.m.

The TAIFEX, a purely order-driven market, accepts two order types: limit orders and market orders. In addition to the transaction price and volume of the latest matched trade, the ETS system displays the five best bid and ask prices and the number of contracts demanded or offered at the five best bid and ask quotes. 


\section{EMPIRICAL DESIGN AND DATA}

(i) Construction of Variables

This study employed the variable construction methods of Ahn et al. (2001), and the time interval was fifteen minutes. ${ }^{3}$

\section{(a) Short-Term Price Volatility}

The short-term price volatility $\left(\mathrm{RISK}_{t}\right)$ during the time interval $t$ is defined as:

$$
\operatorname{RISK}_{t}=\sum_{i=1}^{N} R_{i, t}^{2}
$$

where $R_{i, t}$ denotes the return of the $i$ th transaction during time interval $t$, and $N$ represents the total volume (number) of transactions within the time interval $t$. Meanwhile, the upside volatility $\left(\mathrm{PRISK}_{t}\right)$ is calculated as $\sum_{R_{i, t}>0} R_{i, t}^{2}$ for the positive return observations while the downside volatility $\left(\mathrm{NRISK}_{t}\right)$ is calculated as $\sum_{R_{i, t}<0} R_{i, t}^{2}$ for the negative return observations.

\section{(b) Market Depth and Order Flow}

This study measures market depth based on the order size and the order number. The market depth $\left(\right.$ DEPTHVOL $_{t}\left(\right.$ DEPTHORD $\left.\left._{t}\right)\right)$ is determined by total limit order size (number of limit orders) posted at the best five bid and ask quotes at the end of time interval $t$. Further, the market depth at the bid and ask quotes (DEPTHVOL $t_{t}^{\text {bid }}$, DEPTHVOL $_{t}^{a s k}\left(\right.$ DEPTHORD $_{t}^{\text {bid }}$, DEPTHORD $\left.\left.{ }_{t}^{a s k}\right)\right)$ is also calculated. The change in market depth over the interval $t\left(\triangle \mathrm{DEPTHVOL}_{t}\right.$ and $\left.\triangle \mathrm{DEPTHORD}_{t}\right)$ can be defined as:

$$
\begin{aligned}
\Delta \text { DEPTHVOL }_{t} & =\mathrm{NPLO}_{t}-\text { VOLUME }_{t} \\
\Delta \text { DEPTHORD }_{t} & =\mathrm{NPLON}_{t}-\mathrm{NTRADE}_{t}
\end{aligned}
$$

where $\mathrm{NPLO}_{t}\left(\mathrm{NPLON}_{t}\right)$ denotes the size (number) of newly placed limit orders during time interval $t$, and $\mathrm{VOLUME}_{t}\left(\mathrm{NTRADE}_{t}\right)$ is the size (number) of trades during time interval $t$. The variable $\Delta \mathrm{DEPTHVOL}_{t}\left(\Delta \mathrm{DEPTHORD}_{t}\right)$ measures the order-flow information related to the preferences of liquidity traders who submit limit orders rather than market orders. Additionally, the buy side order-flow information for the size (number) of orders is calculated as follows: DIFFVOL $_{t}^{b u y}\left(\operatorname{DIFFORD}_{t}^{\text {buy }}\right)$ )

$$
\begin{aligned}
& \operatorname{DIFFVOL}_{t}^{b u y}=\Delta \text { DEPTHVOL }_{t}^{\text {bid }}+\operatorname{VOLUME}_{t}^{\text {sell }}-\operatorname{VOLUME}_{t}^{\text {buy }} \\
& \operatorname{DIFFORD~}_{t}^{\text {buy }}=\Delta \text { DEPTHORD }_{t}^{\text {bid }}+\operatorname{NTRADE}_{t}^{\text {sell }}-\operatorname{NTRADE}_{t}^{\text {buy }}
\end{aligned}
$$


where $\triangle$ DEPTHVOL $_{t}^{\text {bid }}\left(\triangle \mathrm{DEPTHORD}_{t}^{\text {bid }}\right)$ is the change in market depth measured as the size (number) of trades at the bid side, $\mathrm{VOLUME}_{t}^{\text {sell }}\left(\mathrm{NTRADE}_{t}^{\text {sell }}\right)$ is the trading size (number) at the sell side and $\operatorname{VOLUME}_{t}^{b u y}\left(\mathrm{NTRADE}_{t}^{b u y}\right)$ is the trading size (number) at buy side. The DIFFVOL ${ }_{t}^{b u y}$ (DIFFORD ${ }_{t}^{\text {buy }}$ ) assesses the difference between newly placed limit orders and market orders at the buy side. Similar variables can be developed for order-flow information at the sell side, as follows:

$$
\begin{aligned}
& \operatorname{DIFFVOL}_{t}^{\text {sell }}=\Delta \mathrm{DEPTHVOL}_{t}^{\text {ask }}+\mathrm{VOLUME}_{t}^{\text {buy }}-\operatorname{VOLUME}_{t}^{\text {sell }} \\
& \text { DIFFORD }_{t}^{\text {sell }}=\Delta \mathrm{DEPTHORD}_{t}^{\text {ask }}+\mathrm{NTRADE}_{t}^{\text {buy }}-\mathrm{NTRADE}_{t}^{\text {sell }}
\end{aligned}
$$

where $\triangle \mathrm{DEPTHVOL}_{t}^{a s k}\left(\triangle \mathrm{DEPTHORD}_{t}^{\text {ask }}\right)$ is the change in market depth measured as the trading size (number) at the ask side.

\section{(ii) Bull and Bear Markets}

This study employs the definition and method for bull and bear markets devised by Lunde and Timmermann (2004). The advantage of their method is its capability of partitioning and differentiating data series into mutually exclusive and exhaustive bull and bear market subsets, which enables systematic analysis of up and down movement rather than merely short-term price movement.

Assuming $I_{t}$ is a bull market indicator with a value of 1 if the stock market is a bull market at time $t$ and zero otherwise, the current price at time $t$ is $P_{t}, \lambda_{1}$ is the threshold percentage of price movement triggering a switch from a bear market to a bull market, and $\lambda_{2}$ is the threshold percentage of price movement triggering a switch from a bull market to a bear market. Further, if the stock market is currently at a local maximum, where $I_{t}=1$, the current maximum price is $P_{t}^{\max }=P_{t}$. The stopping time variables $\tau_{\max }$ and $\tau_{\text {min }}$ then are defined as follows:

$$
\begin{gathered}
\tau_{\max }\left(P_{t}^{\text {max }}, t \mid I_{t}=1\right)=\inf \left\{t+\tau: P_{t+\tau} \geq P_{t}^{\text {max }}\right\} \\
\tau_{\text {min }}\left(P_{t}^{\text {max }}, t, \lambda_{2} \mid I_{t}=1\right)=\inf \left\{t+\tau: P_{t+\tau}<\left(1-\lambda_{2}\right) P_{t}^{\text {max }}\right\}
\end{gathered}
$$

where $\tau \geq 1$. Let $\tau_{s}=\min \left(\tau_{\max }, \tau_{\min }\right)$ denote the first passage time at which the stock price crosses one of two threshold values, $P_{t}^{\max }$ and $\left(1-\lambda_{2}\right) P_{t}^{\max }$. If $\tau_{s}=\tau_{\text {max }}$, meaning that the bull market continues until time $t+\tau_{s}$, the current maximum price is updated to the stock price at time $t+\tau_{s}$, namely, $P_{t+\tau_{s}}^{\max }=P_{t+\tau_{s}}$.

Conversely, if $\tau_{s}=\tau_{\text {min }}$, then the stock price falls and crosses through the threshold barrier $\left(1-\lambda_{2}\right) P_{t}^{\max }$ between $t$ and $t+\tau_{s}$. Accordingly, the stock market enters a bear market phase at time $t$ and continues until time $t+\tau_{s}$. The current minimum price is set as equal to the stock price at time $t+\tau_{s}$, namely, $P_{t+\tau_{s}}^{\min }=P_{t+\tau_{s}}$. When the stock price is at the local minimum when $I_{t}=0$, the stopping time variables $\tau_{\max }$ and $\tau_{\min }$ are defined as follows:

$$
\begin{gathered}
\tau_{\max }\left(P_{t}^{\min }, t, \lambda_{1} \mid I_{t}=0\right)=\inf \left\{t+\tau: P_{t+\tau}>\left(1+\lambda_{1}\right) P_{t}^{\min }\right\} \\
t_{\min }\left(P_{t}^{\min }, t \mid I_{t}=0\right)=\inf \left\{t+\tau: P_{t+\tau} \leq P_{t}^{\min }\right\}
\end{gathered}
$$


where $\tau \geq 1$. Let $\tau_{s}=\min \left(\tau_{\max }, \tau_{\min }\right)$ denote the first passage of time during which the stock price crosses over one of two threshold values $P_{t}^{\min }$ and $\left(1+\lambda_{1}\right) P_{t}^{\min }$. If $\tau_{s}=$ $\tau_{\text {min }}$, the bear market continues until time $t+\tau_{s}$, and the current minimum price is updated to the stock price at time $t+\tau_{s}$, i.e., $P_{t+\tau_{s}}^{\min }=P_{t+\tau_{s}}$. If $\tau_{s}=\tau_{\max }$, the stock price rises and crosses through the threshold barrier, $\left(1+\lambda_{1}\right) P_{t}^{\min }$ between $t$ and $t+\tau_{s}$. Thus, the stock market enters a bull market phase at time $t$, and this phase continues until time $t+\tau_{s}$. The current maximum price is then set as equal to the stock price at time $t+\tau_{s}$, i.e., $P_{t+\tau_{s}}^{\max }=P_{t+\tau_{s}}$. This justification process of bull and bear markets is repeated until all the data has been used up.

The above process regarding the bull and bear markets depends on the threshold percentage values of $\lambda_{1}$ and $\lambda_{2}$. The difficulty of switching from bear (bull) to bull (bear) markets increases with the values of $\lambda_{1}\left(\lambda_{2}\right)$. Therefore, this study considers four pairs, namely $\left(1 \sigma_{s}, 1 \sigma_{s}\right),\left(0.5 \sigma_{s}, 0.5 \sigma_{s}\right),\left(1 \sigma_{s}, 0.5 \sigma_{s}\right)$ and $\left(0.5 \sigma_{s}, 1 \sigma_{s}\right),{ }^{4}$ denoted as $\mathrm{BB} 1, \mathrm{BB} 2, \mathrm{BB} 3$ and $\mathrm{BB} 4$, respectively, where $\sigma_{s}$ represents the daily standard deviation of the TAIEX index returns from 2002 to 2003.

\section{(iii) Data}

The intradaily data for TAIFEX futures contracts were obtained from the Taiwan Economic Journal (TEJ) database from 2002 to 2003, which includes 497 trading days. The TEJ database contains price-and-volume records with all transactions and quotes recorded up to the nearest second via a time stamp. Meanwhile, the quote records of the TEJ database contain the five best bid and ask quotes, the number of futures contracts and the number of orders made at each of the five best bid and ask quotes. The futures contracts are generally the most actively traded contracts and are rolled over to the next nearby futures contract five days before expiration to avoid the expiration effect. To elucidate the influence of institutional trading ${ }^{5}$ on liquidity provision behavior, the ratio of daily institutional trading to total trading volume in one day is computed. ${ }^{6}$ Sample data are then classified as high or low institutional trading subsamples according to the medium of the institutional trading ratios.

Figure 1 shows the daily Taiwan Stock Exchange Capitalization Weighted indices (TAIEX) during the sample period. The movement of the TAIEX was roughly downward in 2002 but upward in 2003. Figure 2 illustrates patterns of market depth and price volatility for twenty 15-minute intervals during a trading day. Similar to the findings of Ahn et al. (2001), Biasi et al. (1995) and Chung and Zhao (2004), a U-shaped volatility pattern and an inverted U-shaped market depth pattern are observed. This statistical result is consistent with Biais et al. (1995), Ahn et al. (2001) and Chung and Zhao (2004). Thus, volatility and market depth are influenced by a seasonality effect.

Table 1 lists the basic descriptive statistics for the TAIEX futures sample studied here. For the entire data set, the average trading volume of 17,670 contracts per day is much higher than the average 3,652 contracts per day during 1999. The average

4 Several other threshold values were tried as well and results were similar to those reported here.

5 Institutional traders include security and futures dealers, commodity pool operators, mutual fund managers and commercial firms.

6 There are five trading days without institutional trading data. Therefore, the number of observations for empirical results of the institutional trading effect is 492 trading days. 
Figure 1

Daily Taiwan Stock Exchange Capitalization Weighted Indices from 2002 to 2003

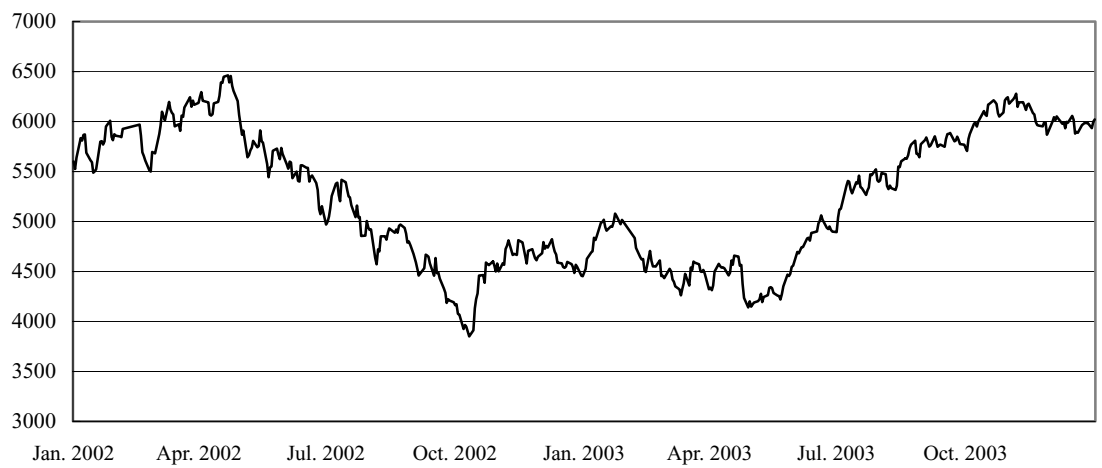

Notes:

This graph displays the pattern of daily Taiwan Stock Exchange Capitalization Weighted Indices from 2002 to 2003, which includes 497 trading days.

Figure 2

Intraday Pattern of Market Depth and Price Volatility

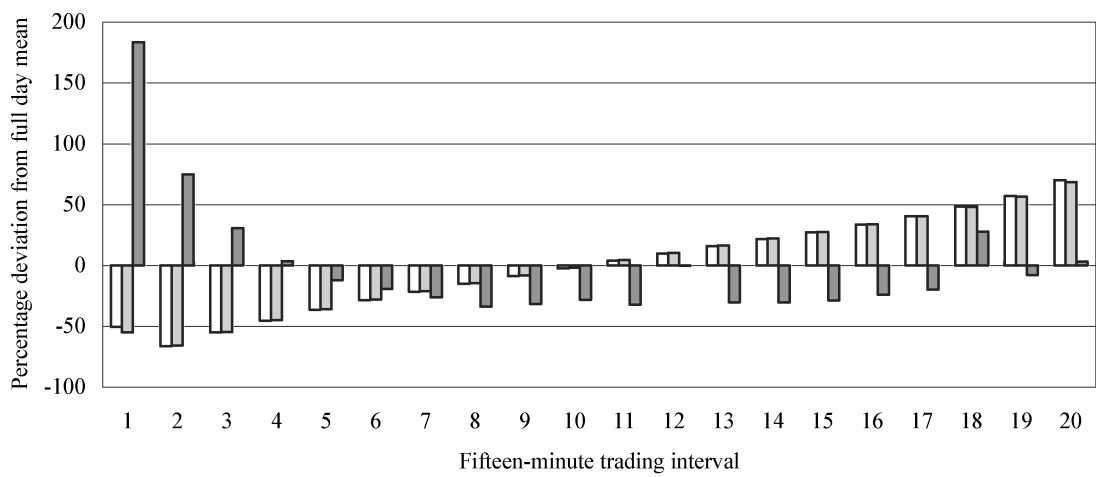

$\square$ Limit order size $\square$ Number of limit orders $\square$ Volatility

Notes:

This graph displays means of limit order size, number of limit orders, and price volatility. All data are shown as percentage deviations from their respective full-day averages for each of the 20 fifteen-minute trading intervals into which the trading day is divided (from 8:45 a.m. to 1:45 p.m.).

number of trades is 9,639. Further, the mean spread is 2.231 index points, which exceeds one tick size of one index point. Generally, the means of cumulative returns, trading volume, number of trades, order imbalance by size and number of orders and institutional trading ratios were larger in 2003 than in 2002, while the average spread was larger in 2002. A possible explanation is the differing trends between 2002 and 2003. Therefore, the following empirical analyses separate sample data into 2002 and 2003 subsamples to compare liquidity provision behavior for these two years.

Table 2 lists the basic descriptive statistics of data in bull and bear markets. Generally, average cumulative return is positive in bull markets, while average cumulative return 
Table 1

Descriptive Statistics for TAIFEX Trading from 2002 to 2003

\begin{tabular}{|c|c|c|c|c|c|c|c|c|c|}
\hline Variable & Price & Spread & $\begin{array}{c}\text { Spread } \\
(\%)\end{array}$ & Return & $\begin{array}{l}\text { No. of } \\
\text { Trades }\end{array}$ & Volume & Imb_Order & $I m b_{-} V o l$ & Inst_Ratio \\
\hline \multicolumn{10}{|c|}{ Panel A: Whole Period } \\
\hline Mean & 5,182 & 2.231 & 0.011 & 0.005 & 9,639 & 17,670 & 0.010 & 0.003 & 0.133 \\
\hline Std Dev & 643 & 1.279 & 0.006 & 0.069 & 4,852 & 9,891 & 0.057 & 0.034 & 0.060 \\
\hline Min & 3,853 & 1.235 & 0.005 & -0.174 & 212 & 259 & -0.342 & -0.138 & 0.040 \\
\hline Median & 5,181 & 1.950 & 0.010 & 0.006 & 9,385 & 16,567 & 0.008 & 0.001 & 0.122 \\
\hline $\operatorname{Max}$ & 6,390 & 14.066 & 0.061 & 0.212 & 23,402 & 46,576 & 0.196 & 0.158 & 0.468 \\
\hline Obs & 497 & 497 & 497 & 497 & 497 & 497 & 497 & 497 & 492 \\
\hline \multicolumn{10}{|c|}{ Panel B: Year of 2002} \\
\hline Mean & 5,203 & $2.701^{* * *}$ & $0.013^{* * *}$ & $-0.010^{* * *}$ & $8,187^{* * *}$ & $13,936^{* * *}$ & 0.008 & 0.003 & $0.096^{* * *}$ \\
\hline Std Dev & 657 & 1.568 & 0.007 & 0.073 & 3,909 & 6,637 & 0.052 & 0.083 & 0.032 \\
\hline Min & 3,853 & 1.490 & 0.007 & -0.174 & 212 & 259 & -0.342 & -0.306 & 0.040 \\
\hline Median & 5,158 & 2.274 & 0.011 & -0.009 & 8,320 & 14,575 & 0.008 & 0.002 & 0.091 \\
\hline Max & 6,390 & 14.066 & 0.061 & 0.212 & 20,688 & 34,992 & 0.196 & 0.376 & 0.258 \\
\hline Obs & $\begin{array}{c}248 \\
(49.9)\end{array}$ & $\begin{array}{c}248 \\
(49.9)\end{array}$ & $\begin{array}{c}248 \\
(49.9)\end{array}$ & $\begin{array}{c}248 \\
(49.9)\end{array}$ & $\begin{array}{l}248 \\
(49.9)\end{array}$ & $\begin{array}{c}248 \\
(49.9)\end{array}$ & $\begin{array}{c}248 \\
(49.9)\end{array}$ & $\begin{array}{c}248 \\
(49.9)\end{array}$ & $\begin{array}{c}243 \\
(49.4)\end{array}$ \\
\hline \multicolumn{10}{|c|}{ Panel C: Year of 2003} \\
\hline Mean & 5,162 & 1.763 & 0.009 & 0.020 & 11,091 & 21,404 & 0.011 & 0.004 & 0.169 \\
\hline Std Dev & 629 & 0.617 & 0.004 & 0.061 & 5,259 & 11,136 & 0.061 & 0.032 & 0.059 \\
\hline Min & 4,123 & 1.235 & 0.005 & -0.136 & 439 & 582 & -0.175 & -0.076 & 0.083 \\
\hline Median & 5,204 & 1.593 & 0.008 & 0.020 & 10,970 & 20,546 & 0.007 & 0.001 & 0.156 \\
\hline Max & 6,161 & 5.988 & 0.031 & 0.171 & 23,402 & 46,576 & 0.185 & 0.153 & 0.468 \\
\hline Obs & $\begin{array}{r}249 \\
(50.1)\end{array}$ & $\begin{array}{c}249 \\
(50.1)\end{array}$ & $\begin{array}{c}249 \\
(50.1)\end{array}$ & $\begin{array}{c}249 \\
(50.1)\end{array}$ & $\begin{array}{l}249 \\
(50.1)\end{array}$ & $\begin{array}{c}249 \\
(50.1)\end{array}$ & $\begin{array}{c}249 \\
(50.1)\end{array}$ & $\begin{array}{c}249 \\
(50.1)\end{array}$ & $\begin{array}{c}249 \\
(50.6)\end{array}$ \\
\hline
\end{tabular}

Notes:

The sample period runs from January 1, 2002 to December 31, 2003, and comprises 497 trading days during which there are five trading days without institutional trading data. Price is the daily price in index points for the most actively traded future contracts. Moreover, spread indicates the daily difference between the best bid and ask prices in index points. Furthermore, spread percentage is the daily percentage of the spread divided by the midpoint of the best bid and ask prices. Return is the cumulative daily return of Taiwan Stock Exchange Capitalization Weighted Index from $t-20$ to $t-1$. Number of trades is the daily number of trades for the most actively traded futures contracts. Volume represents the average daily volume of trades for the most actively traded futures contracts. Imb_order is the daily difference between number of buy and number of sell limit orders divided by the daily sum of number of buy and sell limit orders. Imb_vol is the daily difference between the buy and sell limit order sizes divided by the sum of daily buy and sell limit sizes. Finally, Inst_ratio represents the ratio of daily institutional trading volume to the daily trading volume. The ratios in parentheses show percentages of observations to the whole sample. Mann-Whitney-Wilcoxon tests are performed for the differences between all variables in 2002 and $2003 .{ }^{*},{ }^{* *},{ }^{* *}$ denote significance levels at $10 \%, 5 \%$ and $1 \%$, respectively.

is negative in bear markets. Additionally, average spreads, average number of trades and average order imbalance by size are larger in bull markets than in bear markets. Although institutional trading ratios are slightly higher in bear markets, the increase is not statistically significant. Apparently, trading is much more intensive in bull markets than in bear markets, since the bull markets involve relatively higher average trading volume and higher average number of trades in all cases. Conversely, the order imbalance by number of orders is larger in bear than in bull markets. This shows that traders submit more limit buy orders than limit sell orders when the market undergoes a decline. This could be due to a greater information asymmetry problem in bear markets, which causes liquidity traders to submit limit buy orders instead of market buy orders to avoid the adverse selection problem on the buy side. 


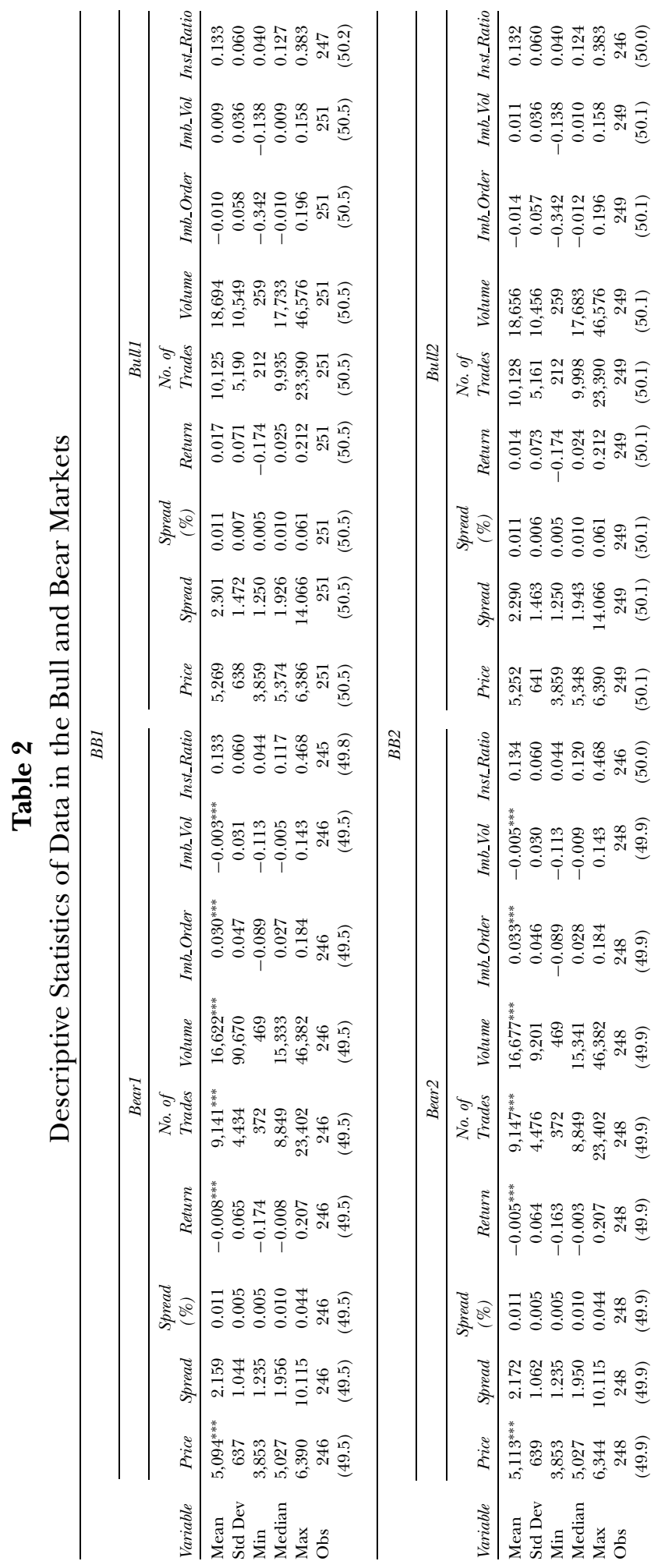




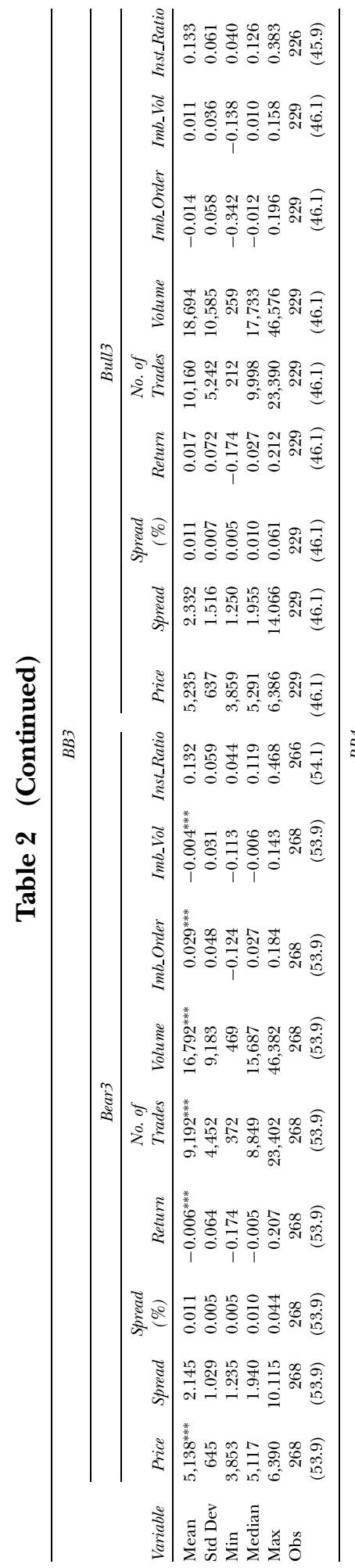

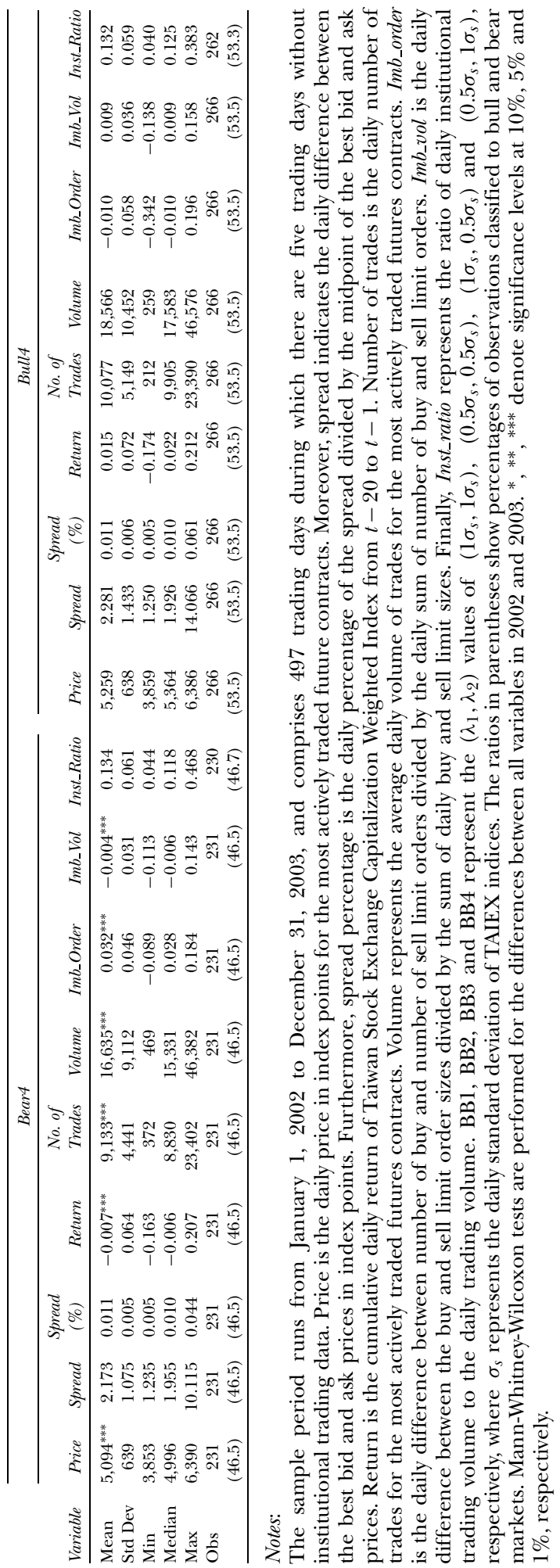




\section{EMPIRICAL FINDINGS}

\section{(i) Impact of Transient Volatility on Subsequent Market Depth}

Table 3 summarizes the estimation results for the effect of transient volatility on subsequent market depth, as measured by limit order size and number of limit orders. Under the market depth measured by limit order size, the coefficients of transient volatility, $\beta_{1}$, are insignificantly positive for the entire data set and years of 2002 and 2003. On the other hand, when market depth measured by the number of limit orders, the coefficient of transient volatility, $\gamma_{1}$, is significantly positive for the year of 2002. This weakly supports an idea that subsequent market depth is significantly and positively related to transient volatility, which is consistent with the finding of Ahn et al. (2001) that increased transient volatility leads to increased liquidity trading.

Estimation results for the bull and bear markets indicate that the coefficient of transient volatility, $\beta_{1}$, is significantly positive in bull markets and is significantly negative in bear markets. Therefore, during bull markets, the trade size of limit orders increase after transient volatility increases, while traders reduce the size of their trades during bear markets. The above findings demonstrate the asymmetric effects of liquidity trading during different market trends. This indicates that liquidity investors prefer to reduce trade size to avoid the adverse selection problem. This condition occurs because investors cannot determine whether the increased volatility is caused by informed trading activity or liquidity trading activity. Therefore, the best investment strategy for liquidity investors is reducing their trades.

The above findings corroborate those of Ahn et al. (2001), that increased transient volatility leads to increased liquidity trading in bull markets but not in bear markets. Most studies report that stock markets respond asymmetrically to upward and downward trends. (Nelson, 1991; Engle and Ng, 1993; Glosten et al., 1993; and Koutmos, 1998). Generally, negative return shocks influence the market more than positive return shocks do. By reducing quoted trade size, liquidity traders can limit their losses to informed traders and limit the extent of information asymmetry during bear markets. Consequently, liquidity traders tend to avoid aggressive trading during bear markets.

When market depth is measured by the number of limit orders, the coefficient of transient, $\gamma_{1}$, is significantly positive in the bull market but insignificantly negative in the bear market. This phenomenon is consistent with the above findings using limit order size as the market depth. Therefore, transient volatility and subsequent market depth are positively related in bull markets but not in bear markets. The empirical findings presented here indicate that liquidity traders in the index futures market tend to react asymmetrically to changes in transient volatility. When transient volatility increases, liquidity trading intensifies during bull markets but not in bear markets.

Regarding the influence of market trading intensity on market depth, market depth as measured by limit order size tends to be higher when trading volume increases, since $\beta_{2}$, the coefficient of trading volume, is significantly positive for the whole data set, the bull and bear markets. However, when market depth is measured by the number of limit orders, the coefficient of the number of trades $\gamma_{2}$ is significantly negative for all classifications. These analytical results indicate that investors are inclined to increase their quoted size when trading activity intensifies, even if it exhausts the number of limit orders. 


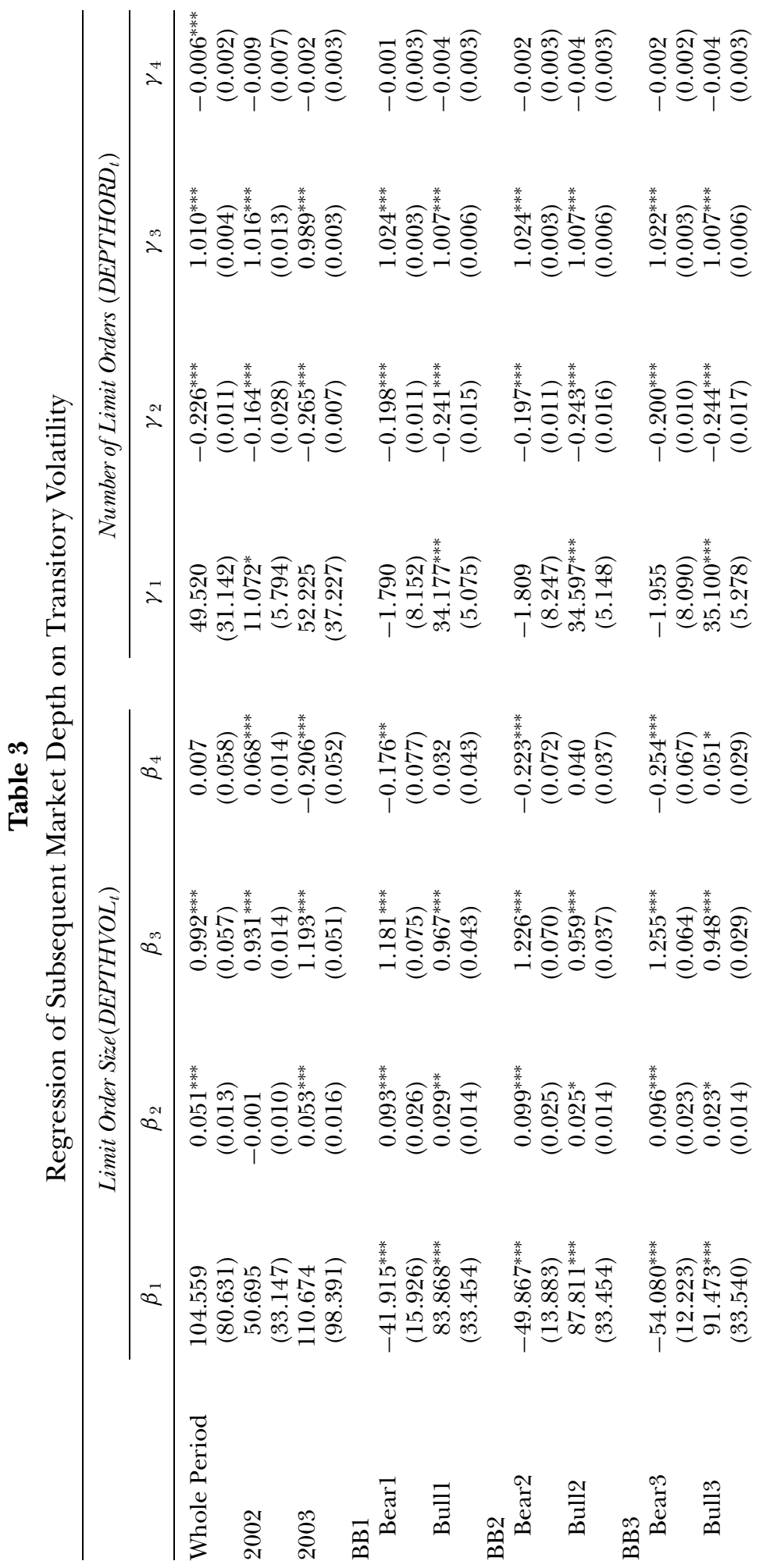




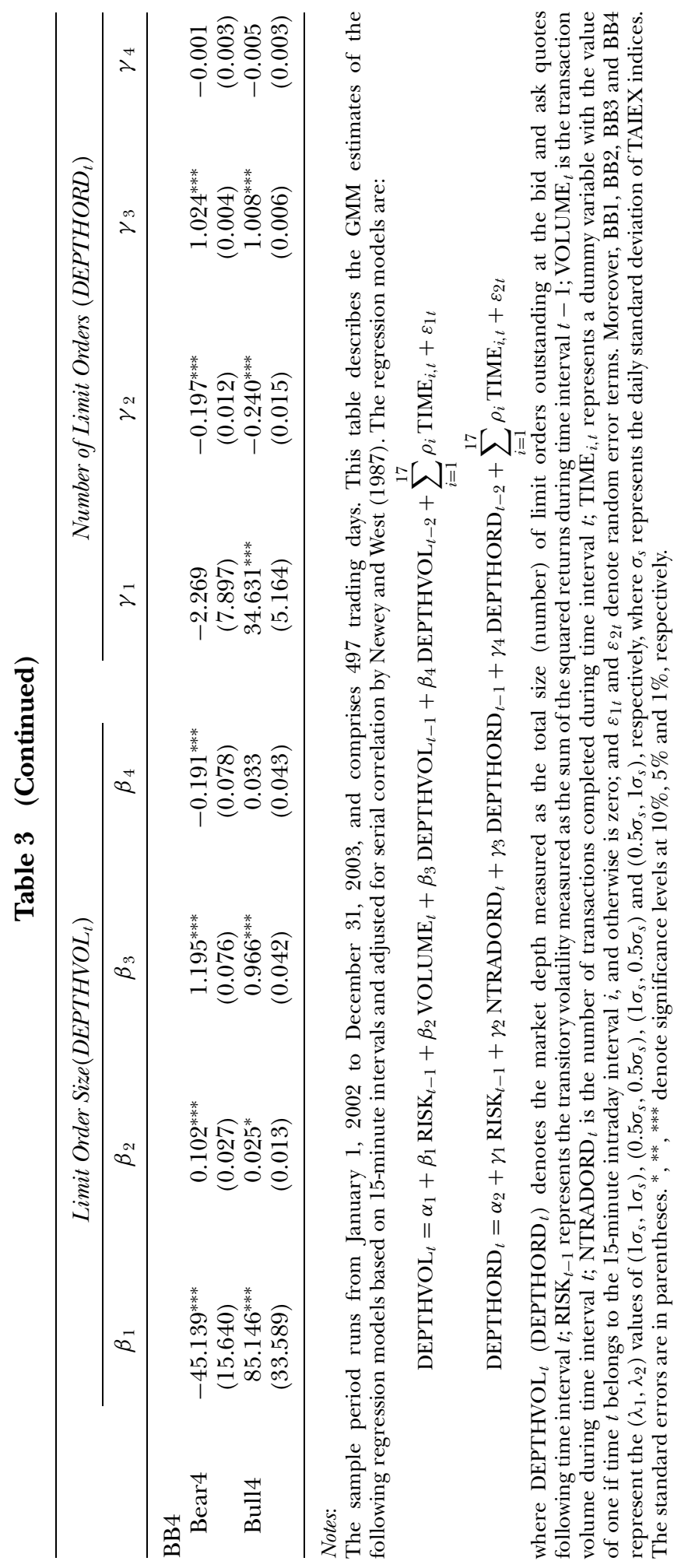




\section{(ii) Impact of Transient Volatility on Subsequent Increments on Market Depth}

Table 4 lists the estimation results for the effect of transient volatility on the subsequent increment on market depth. The relationship between transient volatility and subsequent increments on market depth is insignificantly and positively correlated

Table 4

Regression of Subsequent Market Depth Change on Transitory Volatility

\begin{tabular}{|c|c|c|c|c|}
\hline & \multicolumn{2}{|c|}{$\begin{array}{l}\text { Limit Order Sizes } \\
\left(\triangle D E P T H V O L_{t}\right)\end{array}$} & \multicolumn{2}{|c|}{$\begin{array}{l}\text { Number of Limit Orders } \\
\left(\triangle D E P T H O R D_{t}\right)\end{array}$} \\
\hline & $\beta_{1}$ & $\beta_{2}$ & $\gamma_{1}$ & $\gamma_{2}$ \\
\hline Whole Period & $\begin{array}{l}109.880 \\
(78.726)\end{array}$ & $\begin{array}{r}-0.010 \\
(0.057)\end{array}$ & $\begin{array}{c}22.830 \\
(36.553)\end{array}$ & $\begin{array}{l}0.005^{* *} \\
(0.003)\end{array}$ \\
\hline 2002 & $\begin{array}{c}50.047 \\
(32.274)\end{array}$ & $\begin{array}{l}-0.070^{* * *} \\
(0.012)\end{array}$ & $\begin{array}{r}-40.164 \\
(31.984)\end{array}$ & $\begin{array}{l}0.003^{* * *} \\
(0.001)\end{array}$ \\
\hline 2003 & $\begin{array}{l}116.205 \\
(95.887)\end{array}$ & $\begin{array}{l}0.194^{* * *} \\
(0.051)\end{array}$ & $\begin{array}{c}30.953 \\
(40.313)\end{array}$ & $\begin{array}{l}0.035^{* * *} \\
(0.002)\end{array}$ \\
\hline \multicolumn{5}{|l|}{ BB1 } \\
\hline Bear1 & $\begin{array}{r}-26.281^{*} \\
(14.709)\end{array}$ & $\begin{array}{l}0.177^{* *} \\
(0.074)\end{array}$ & $\begin{array}{c}-31.372^{* * *} \\
(3.404)\end{array}$ & $\begin{array}{l}0.034^{* * *} \\
(0.002)\end{array}$ \\
\hline Bull1 & $\begin{array}{l}84.831^{* * *} \\
(32.985)\end{array}$ & $\begin{array}{r}-0.036 \\
(0.042)\end{array}$ & $\begin{array}{l}19.006 \\
(12.374)\end{array}$ & $\begin{array}{l}0.003^{* *} \\
(0.002)\end{array}$ \\
\hline \multicolumn{5}{|l|}{ BB2 } \\
\hline Bear2 & $\begin{array}{l}-33.564^{* * *} \\
(12.496)\end{array}$ & $\begin{array}{l}0.221^{* * *} \\
(0.069)\end{array}$ & $\begin{array}{c}-30.748^{* * *} \\
(3.609)\end{array}$ & $\begin{array}{l}0.034^{* * *} \\
(0.002)\end{array}$ \\
\hline Bull2 & $\begin{array}{l}88.676^{* * *} \\
(33.031)\end{array}$ & $\begin{array}{c}-0.043 \\
(0.036)\end{array}$ & $\begin{array}{l}18.666 \\
(12.948)\end{array}$ & $\begin{array}{l}0.003^{* *} \\
(0.002)\end{array}$ \\
\hline \multicolumn{5}{|l|}{ BB3 } \\
\hline Bear3 & $\begin{array}{l}-38.329^{* * *} \\
(10.925)\end{array}$ & $\begin{array}{l}0.250^{* * *} \\
(0.064)\end{array}$ & $\begin{array}{c}-30.370^{* * *} \\
(3.735)\end{array}$ & $\begin{array}{l}0.034^{* * *} \\
(0.002)\end{array}$ \\
\hline Bull3 & $\begin{array}{l}92.323^{* * *} \\
(33.132)\end{array}$ & $\begin{array}{c}-0.054^{* *} \\
(0.028)\end{array}$ & $\begin{array}{c}19.524 \\
(12.836)\end{array}$ & $\begin{array}{l}0.003^{* *} \\
(0.002)\end{array}$ \\
\hline \multicolumn{5}{|l|}{ BB4 } \\
\hline Bear4 & $\begin{array}{l}-28.358^{* *} \\
(14.228)\end{array}$ & $\begin{array}{l}0.190^{* * *} \\
(0.075)\end{array}$ & $\begin{array}{c}-31.013^{* * *} \\
(3.566)\end{array}$ & $\begin{array}{l}0.034^{* * *} \\
(0.003)\end{array}$ \\
\hline Bull4 & $\begin{array}{l}86.029^{* * *} \\
(33.161)\end{array}$ & $\begin{array}{r}-0.036 \\
(0.042)\end{array}$ & $\begin{array}{c}18.447 \\
(12.847)\end{array}$ & $\begin{array}{l}0.004^{* *} \\
(0.002)\end{array}$ \\
\hline
\end{tabular}

Notes:

The sample period runs from January 1, 2002 to December 31, 2003, and comprises 497 trading days. This table illustrates the GMM estimates of the following regression models based on 15-minute intervals and adjusted for serial correlation by Newey and West (1987). The regression models are:

$$
\begin{aligned}
& \triangle \text { DEPTHVOL }_{t}=\alpha_{1}+\beta_{1} \text { RISK }_{t-1}+\beta_{2} \Delta \text { DEPTHVOL }_{t-1}+\sum_{i=1}^{17} \rho_{i} \operatorname{TIME}_{i, t}+\varepsilon_{1 t} \\
& \Delta \text { DEPTHORD }_{t}=\alpha_{2}+\gamma_{1} \operatorname{RISK}_{t-1}+\gamma_{2} \Delta \text { DEPTHORD }_{t-1}+\sum_{i=1}^{17} \rho_{i} \operatorname{TIME}_{i, t}+\varepsilon_{2 t}
\end{aligned}
$$

where $\triangle$ DEPTHVOL $_{t}\left(\triangle\right.$ DEPTHORD $\left._{t}\right)$ denotes the change of market depth measured as the total size (number) of limit orders outstanding at the bid and ask quotes from time interval $t-1$ to $t$; RISK $t-1$ denotes the transitory volatility measured as the sum of the squared returns during time interval $t-1$; $\mathrm{TIME}_{i, t}$ represents a dummy variable that takes the value of one if time $t$ belongs to the 15-minute intraday interval $i$, and zero otherwise; and $\varepsilon_{1 t}$ and $\varepsilon_{2 t}$ are random error terms. Moreover, BB1, BB2, BB3 and BB4 represent the $\left(\lambda_{1}, \lambda_{2}\right)$ values of $\left(1 \sigma_{s}, 1 \sigma_{s}\right),\left(0.5 \sigma_{s}, 0.5 \sigma_{s}\right),\left(1 \sigma_{s}, 0.5 \sigma_{s}\right)$ and $\left(0.5 \sigma_{s}, 1 \sigma_{s}\right)$ respectively, where $\sigma_{s}$ represents the daily standard deviation of TAIEX indices. The standard errors are in parentheses. *, **, *** denote significance levels of $10 \%, 5 \%$ and $1 \%$, respectively. 
for the entire data set and years of 2002 and 2003. Additionally, transient volatility is negatively related to the subsequent increment on market depth as measured either by limit order size or by number of orders in bear markets. Therefore, as risk increases, liquidity traders tend to reduce their increments of limit orders in bear markets. Coupled with the finding in Table 3 , that increased transient volatility causes liquidity traders to reduce their placements of limit orders during bear markets, liquidity traders do not aggressively provide liquidity in the futures market during bear markets when the transient risk increases. This phenomenon is consistent with Glosten and Milgrom (1985) and Glosten (1994), who proposed that competitive traders may choose not to quote if the adverse selection problem is too extreme.

Conversely, bull markets reveal a significant positive relationship between transient volatility and the subsequent increment in market depth. In bull markets, liquidity traders submit limit orders more aggressively than market orders as liquidity-driven transient volatility increases. Ahn et al. (2001), in a study of the Hong Kong Stock Exchange, found only weak support for this relationship. In this study, the relationship of increases in increments in market depth following increases in transient volatility is significantly supported in bull but not in bear markets.

In contrast with the negative autocorrelation reported by Ahn et al. (2001), Table 4 describes the positive autocor relation of increments in mark et depth measured by the number of limit orders. Thus, the number of limit orders increases (decreases) following an increase (decrease) in the number of limit orders. This relationship may reflect an order submission situation in which liquidity traders follow their previously established trading patterns. This finding may result from the order persistence phenomenon identified by Lin et al. (1995) and Hasbrouck (1991), namely, that buy (sell) orders tend to follow buy (sell) orders.

Table 5 lists the estimation results when the increment of mark et depth is divid ed into buy and sell sides, represented by DIFFVOL ${ }^{\text {buy }}\left(\right.$ DIFFORD $\left.^{\text {buy }}\right)$ and DIFFVOL $^{\text {sell }}$ $\left(\right.$ DIFFORD $\left.^{\text {sell }}\right)$, respectively. Panel A of Table 5 shows a significant positive relationship between the increment market depth on the buy side and upside transient volatility for year 2003, but not for year 2002. Therefore, the relationship between transient volatility and subsequent market depth shows different patterns under different market years when market depth is separated into buy and sell sides. Bear markets exhibit a significantly positive (negative) relationship between the increment in market depth on the buy side and downside (upside) transient volatility. In bull markets, increased upside transient volatility increases the subsequent increment of market depth on the buy side, but no such significant relationship exists between downside transient volatility and market depth on the buy side.

Panel B of Table 5 shows the estimation results of the relationship between the increment of market depth on the sell side, upside volatility and downside volatility. The significantly positive (negative) relationship between the subsequent increment of market depth on sell side and upside (downside) transient volatility is apparent for year 2003 and bear markets when market depth is measured by limit order size. Bull markets reveal a significant positive relationship between the subsequent increment of market depth on the sell side and upside transient volatility, but an insignificantly negative relationship between the subsequent increment of market depth on the sell side and downside transient volatility.

For bear markets, Table 5 reveals a limit order submission situation in which, under increased downside (upside) transient volatility, liquidity traders submit more limit buy 
Table 5

Regression of the Difference Between Limit Buy (Sell) Order and Market Buy (Sell) on Lagged Upside and Downside Volatility

\begin{tabular}{|c|c|c|c|c|c|c|}
\hline \multicolumn{4}{|c|}{$\begin{array}{l}\text { Panel A: Dependent Variable is the Differe } \\
\text { Orders at the Buy Side } \\
\qquad \begin{array}{c}\text { Limit Order Sizes } \\
\left(\text { DIFFVOL } L_{t}^{\text {by }}\right)\end{array}\end{array}$} & \multicolumn{3}{|c|}{$\begin{array}{l}\text { Number of Limit Orders } \\
\left(\text { DIFFORD }_{t}^{\text {buy }}\right)\end{array}$} \\
\hline & $\beta_{1}$ & $\beta_{2}$ & $\beta_{3}$ & $\gamma_{1}$ & $\gamma_{2}$ & $\gamma_{3}$ \\
\hline Whole Period & $\begin{array}{c}13.526 \\
(20.531)\end{array}$ & $\begin{array}{r}-31.058 \\
(66.499)\end{array}$ & $\begin{array}{l}0.455^{* * *} \\
(0.092)\end{array}$ & $\begin{array}{l}10.924^{* * *} \\
(3.002)\end{array}$ & $\begin{array}{c}3.733 \\
(19.115)\end{array}$ & $\begin{array}{r}0.135^{*} \\
(0.079)\end{array}$ \\
\hline 2002 & $\begin{array}{c}-1,295.683^{* * *} \\
(401.603)\end{array}$ & $\begin{array}{l}690.807^{* * *} \\
(183.128)\end{array}$ & $\begin{array}{c}0.244 \\
(0.181)\end{array}$ & $\begin{array}{r}-48.833 \\
(78.358)\end{array}$ & $\begin{array}{l}-3.368 \\
(65.962)\end{array}$ & $\begin{array}{c}0.032 \\
(0.090)\end{array}$ \\
\hline 2003 & $\begin{array}{l}24.672^{* * *} \\
(8.415)\end{array}$ & $\begin{array}{l}-13.744 \\
(71.204)\end{array}$ & $\begin{array}{l}0.526^{* * *} \\
(0.018)\end{array}$ & $\begin{array}{l}7.202^{* * *} \\
(0.890)\end{array}$ & $\begin{array}{l}40.784^{* * *} \\
(13.356)\end{array}$ & $\begin{array}{l}0.207^{* * *} \\
(0.024)\end{array}$ \\
\hline \multicolumn{7}{|l|}{ BB1 } \\
\hline Bear1 & $\begin{array}{c}-1,583.910^{* * *} \\
(221.664)\end{array}$ & $\begin{array}{c}1,967.918^{* * *} \\
(281.443)\end{array}$ & $\begin{array}{l}0.544^{* * *} \\
(0.021)\end{array}$ & $\begin{array}{c}-312.792^{* * *} \\
(107.814)\end{array}$ & $\begin{array}{r}454.9 \\
(140.0\end{array}$ & $\begin{array}{l}0.269^{* * *} \\
(0.029)\end{array}$ \\
\hline Bull1 & $\begin{array}{r}24.529^{*} \\
(13.384)\end{array}$ & $\begin{array}{c}-39.772 \\
(87.662)\end{array}$ & $\begin{array}{l}0.408^{* * *} \\
(0.139)\end{array}$ & $\begin{array}{l}15.176^{* * *} \\
(1.819)\end{array}$ & $\begin{array}{c}-33.525 \\
(23.917)\end{array}$ & $\begin{array}{c}0.057 \\
(0.084)\end{array}$ \\
\hline \multicolumn{7}{|l|}{ BB2 } \\
\hline Bear2 & $\begin{array}{c}-1,537.226^{* * *} \\
(219.010)\end{array}$ & $\begin{array}{c}1,912.356^{* * *} \\
(277.530)\end{array}$ & $\begin{array}{l}0.539^{* * *} \\
(0.021)\end{array}$ & $\begin{array}{l}-324.865^{* * *} \\
(105.770)\end{array}$ & $\begin{array}{l}473.420^{* * *} \\
(136.588)\end{array}$ & $\begin{array}{l}0.266^{* * *} \\
(0.029)\end{array}$ \\
\hline Bull2 & $\begin{array}{r}25.592^{*} \\
(13.894)\end{array}$ & $\begin{array}{c}-47.873 \\
(89.933)\end{array}$ & $\begin{array}{l}0.403^{* * *} \\
(0.141)\end{array}$ & $\begin{array}{l}15.255^{* * *} \\
(2.044)\end{array}$ & $\begin{array}{r}-38.849 \\
(27.469)\end{array}$ & $\begin{array}{c}0.047 \\
(0.082)\end{array}$ \\
\hline \multicolumn{7}{|l|}{ BB3 } \\
\hline Bear3 & $\begin{array}{c}-1,597.628^{* * *} \\
(219.379)\end{array}$ & $\begin{array}{l}1,987.762^{* * *} \\
(278.314)\end{array}$ & $\begin{array}{l}0.535^{* * *} \\
(0.020)\end{array}$ & $\begin{array}{l}-297.954^{* * *} \\
(101.187)\end{array}$ & $\begin{array}{l}436.692^{* * *} \\
(131.253)\end{array}$ & $\begin{array}{l}0.266^{* * *} \\
(0.028)\end{array}$ \\
\hline Bull3 & $\begin{array}{l}26.293^{* *} \\
(13.533)\end{array}$ & $\begin{array}{c}-50.341 \\
(92.796)\end{array}$ & $\begin{array}{l}0.401^{* * *} \\
(0.149)\end{array}$ & $\begin{array}{l}15.493^{* * *} \\
(1.920)\end{array}$ & $\begin{array}{l}-36.961 \\
(26.434)\end{array}$ & $\begin{array}{c}0.044 \\
(0.083)\end{array}$ \\
\hline \multicolumn{7}{|l|}{ BB4 } \\
\hline Bear4 & $\begin{array}{c}-1,599.238^{* * *} \\
(226.809)\end{array}$ & $\begin{array}{c}1,990.555^{* * *} \\
(287.657)\end{array}$ & $\begin{array}{l}0.543^{* * *} \\
(0.022)\end{array}$ & $\begin{array}{c}-356.752^{* * *} \\
(109.921)\end{array}$ & $\begin{array}{l}512.382^{* * *} \\
(142.393)\end{array}$ & $\begin{array}{c}0.270^{\text {*** }} \\
(0.030)\end{array}$ \\
\hline Bull4 & $\begin{array}{r}24.536^{*} \\
(13.809)\end{array}$ & $\begin{array}{c}-42.801 \\
(89.001)\end{array}$ & $\begin{array}{l}0.411^{* * *} \\
(0.135)\end{array}$ & $\begin{array}{l}15.351^{* * *} \\
(1.861)\end{array}$ & $\begin{array}{c}-36.561 \\
(25.863)\end{array}$ & $\begin{array}{c}0.060 \\
(0.084)\end{array}$ \\
\hline
\end{tabular}

Panel B: Dependent Variable is the Difference Between Newly Placed Limit Orders and Market Orders at the Sell Side

\begin{tabular}{|c|c|c|c|c|c|c|}
\hline & \multicolumn{3}{|c|}{$\begin{array}{c}\text { Limit Order Sizes } \\
(\text { DIFFVOL } \\
\text { sell })\end{array}$} & \multicolumn{3}{|c|}{$\begin{array}{l}\text { Number of Limit Orders } \\
(\text { DIFFORD }\end{array}$} \\
\hline & $\beta_{4}$ & $\beta_{5}$ & $\beta_{6}$ & $\gamma_{4}$ & $\gamma_{5}$ & $\gamma_{6}$ \\
\hline Whole Period & $\begin{array}{l}131.343^{* * *} \\
(19.740)\end{array}$ & $\begin{array}{l}-275.593^{* *} \\
(131.240)\end{array}$ & $\begin{array}{l}0.419^{* * *} \\
(0.093)\end{array}$ & $\begin{array}{l}71.355^{* * *} \\
(13.701)\end{array}$ & $\begin{array}{c}-130.675^{* *} \\
(59.636)\end{array}$ & $\begin{array}{c}0.110 \\
(0.082)\end{array}$ \\
\hline 2002 & $\begin{array}{c}-809.321 \\
(543.050)\end{array}$ & $\begin{array}{l}341.620 \\
(299.419)\end{array}$ & $\begin{array}{c}0.220 \\
(0.179)\end{array}$ & $\begin{array}{c}-359.360^{* * *} \\
(133.305)\end{array}$ & $\begin{array}{l}216.776^{* * *} \\
(82.346)\end{array}$ & $\begin{array}{c}-0.010 \\
(0.069)\end{array}$ \\
\hline 2003 & $\begin{array}{c}149.074^{* * *} \\
(5.166)\end{array}$ & $\begin{array}{c}-400.967^{* * *} \\
(49.276)\end{array}$ & $\begin{array}{l}0.481^{* * *} \\
(0.019)\end{array}$ & $\begin{array}{l}83.853^{* * *} \\
(0.956)\end{array}$ & $\begin{array}{c}-232.578^{* * *} \\
(6.417)\end{array}$ & $\begin{array}{l}0.198^{* * *} \\
(0.022)\end{array}$ \\
\hline \multicolumn{7}{|l|}{ BB1 } \\
\hline Bear1 & $\begin{array}{l}942.124^{* * *} \\
(233.102)\end{array}$ & $\begin{array}{l}-1373.361^{* * *} \\
(303.096)\end{array}$ & $\begin{array}{l}0.527^{* * *} \\
(0.022)\end{array}$ & $\begin{array}{l}-13.263 \\
(104.697)\end{array}$ & $\begin{array}{r}-114.819 \\
(131.309)\end{array}$ & $\begin{array}{l}0.192^{* * *} \\
(0.030)\end{array}$ \\
\hline Bull1 & $\begin{array}{l}49.234^{* * *} \\
(5.213)\end{array}$ & $\begin{array}{r}-88.273 \\
(82.960)\end{array}$ & $\begin{array}{l}0.354^{* * *} \\
(0.125)\end{array}$ & $\begin{array}{l}15.824^{* * *} \\
(2.195)\end{array}$ & $\begin{array}{l}-9.767 \\
(14.297)\end{array}$ & $\begin{array}{c}0.069 \\
(0.084)\end{array}$ \\
\hline
\end{tabular}


Table 5 (Continued)

\begin{tabular}{|c|c|c|c|c|c|c|}
\hline & \multicolumn{3}{|c|}{$\begin{array}{l}\text { Limit Order Sizes } \\
\left(\text { DIFFVOL }_{t}^{\text {sell }}\right)\end{array}$} & \multicolumn{3}{|c|}{$\begin{array}{c}\text { Number of Limit Orders } \\
(\text { DIFFORD }\end{array}$} \\
\hline & $\beta_{4}$ & $\beta_{5}$ & $\beta_{6}$ & $\gamma_{4}$ & $\gamma_{5}$ & $\gamma_{6}$ \\
\hline \multicolumn{7}{|l|}{ BB2 } \\
\hline Bear2 & $\begin{array}{l}841.746^{* * *} \\
(231.109)\end{array}$ & $\begin{array}{c}-1237.982^{* * *} \\
(299.727)\end{array}$ & $\begin{array}{l}0.540^{* * *} \\
(0.021)\end{array}$ & $\begin{array}{c}11.221 \\
(99.544)\end{array}$ & $\begin{array}{c}-146.287 \\
(124.716)\end{array}$ & $\begin{array}{l}0.198^{* * *} \\
(0.031)\end{array}$ \\
\hline Bull2 & $\begin{array}{l}50.077^{* * *} \\
(5.662)\end{array}$ & $\begin{array}{c}-94.435 \\
(84.346)\end{array}$ & $\begin{array}{l}0.343^{* * *} \\
(0.123)\end{array}$ & $\begin{array}{l}16.127^{* * *} \\
(2.085)\end{array}$ & $\begin{array}{l}-8.221 \\
(13.902)\end{array}$ & $\begin{array}{c}0.064 \\
(0.081)\end{array}$ \\
\hline \multicolumn{7}{|l|}{ BB3 } \\
\hline Bear3 & $\begin{array}{l}871.395^{* * *} \\
(231.027)\end{array}$ & $\begin{array}{c}-1277.675^{* * *} \\
\quad(298.645)\end{array}$ & $\begin{array}{l}0.526^{* * *} \\
(0.020)\end{array}$ & $\begin{array}{c}-8.664 \\
(100.702)\end{array}$ & $\begin{array}{c}-118.625 \\
(125.913)\end{array}$ & $\begin{array}{l}0.208^{* * *} \\
(0.030)\end{array}$ \\
\hline Bull3 & $\begin{array}{l}50.935^{* * *} \\
(5.558)\end{array}$ & $\begin{array}{c}-95.863 \\
(86.260)\end{array}$ & $\begin{array}{l}0.341^{* * *} \\
(0.130)\end{array}$ & $\begin{array}{l}16.724^{* * *} \\
(2.065)\end{array}$ & $\begin{array}{l}-8.967 \\
(14.094)\end{array}$ & $\begin{array}{c}0.056 \\
(0.081)\end{array}$ \\
\hline \multicolumn{7}{|l|}{ BB4 } \\
\hline Bear4 & $\begin{array}{l}854.740^{* * * *} \\
(235.549)\end{array}$ & $\begin{array}{c}-1257.871^{* * *} \\
(307.149)\end{array}$ & $\begin{array}{l}0.537^{* * *} \\
(0.022)\end{array}$ & $\begin{array}{c}18.537 \\
(105.702)\end{array}$ & $\begin{array}{c}-154.803 \\
(132.364)\end{array}$ & $\begin{array}{l}0.200^{* * *} \\
(0.033)\end{array}$ \\
\hline Bull4 & $\begin{array}{l}49.759^{* * *} \\
(5.416)\end{array}$ & $\begin{array}{c}-94.407 \\
(85.859)\end{array}$ & $\begin{array}{l}0.354^{* * *} \\
(0.121)\end{array}$ & $\begin{array}{l}15.740^{* * *} \\
(2.316)\end{array}$ & $\begin{array}{c}-10.048 \\
(14.528)\end{array}$ & $\begin{array}{c}0.069 \\
(0.082)\end{array}$ \\
\hline
\end{tabular}

Notes:

The sample period runs from January 1, 2002 to December 31, 2003, and comprises 497 trading days. This table shows the GMM estimates of regression models based on 15-minute intervals and adjusted for serial correlation by Newey and West (1987). The regression models are as follows:

$$
\begin{aligned}
& \text { DIFFVOL }_{t}^{\text {buy }}=\alpha_{1}+\beta_{1} \text { PRISK }_{t-1}+\beta_{2} \text { NRISK }_{t-1}+\beta_{3} \operatorname{DIFF}_{t-1}^{\text {buy }}+\sum_{i=1}^{17} \rho_{i} \operatorname{TIME}_{i, t}+\varepsilon_{1 t}^{\text {buy }} \\
& \text { DIFFVOL }_{t}^{\text {sell }}=\alpha_{2}+\beta_{4} \text { PRISK }_{t-1}+\beta_{5} \text { NRISK }_{t-1}+\beta_{6} \operatorname{DIFF}_{t-1}^{\text {sell }}+\sum_{i=1}^{17} \rho_{i} \operatorname{TIME}_{i, t}+\varepsilon_{2 t}^{\text {sell }} \\
& \text { DIFFORD }_{t}^{\text {buy }}=\alpha_{3}+\gamma_{1} \text { PRISK }_{t-1}+\gamma_{2} \operatorname{NRISK}_{t-1}+\gamma_{3} \operatorname{DIFF}_{t-1}^{\text {buy }}+\sum_{i=1}^{17} \rho_{i} \operatorname{TIME}_{i, t}+\varepsilon_{2 t}^{\text {buy }} \\
& \text { DIFFORD }_{t}^{\text {sell }}=\alpha_{4}+\gamma_{4} \text { PRISK }_{t-1}+\gamma_{5} \text { NRISK }_{t-1}+\gamma_{6} \operatorname{DIFF}_{t-1}^{\text {sell }}+\sum_{i=1}^{17} \rho_{i} \operatorname{TIME}_{i, t}+\varepsilon_{2 t}^{\text {sell }}
\end{aligned}
$$

where DIFFVOL ${ }_{t}^{\text {buy }}\left(\right.$ DIFFVOL $\left._{t}^{\text {sell }}\right)$ measures the difference between the size of newly placed limit buy(sell) orders and market buy (sell) orders during time interval $t$; DIFFORD ${ }_{t}^{\text {buy }}\left(\right.$ DIFFORD $\left._{t}^{\text {sell }}\right)$ indicates the difference between the number of newly placed limit buy(sell) orders and market buy (sell) orders during

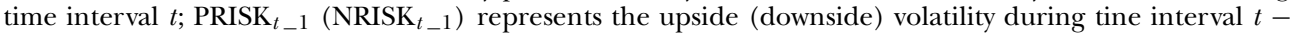
1 , which is measured as the sum of squared returns based on the observation of positive (negative) returns within the interval $t-1$; TIME $i, t$ represents a dummy variable with the value of one if time $t$ belongs to the 15-minute intraday interval $i$, and zero otherwise; and $\varepsilon_{1 t}^{b u y}, \varepsilon_{1 t}^{\text {sell }}, \varepsilon_{2 t}^{b u y}$ and $\varepsilon_{2 t}^{\text {sell }}$ are random error terms. Furthermore, BB1, BB2, BB3 and BB4 represent the $\left(\lambda_{1}, \lambda_{2}\right)$ values of $\left(1 \sigma_{s}, 1 \sigma_{s}\right),\left(0.5 \sigma_{s}, 0.5 \sigma_{s}\right),\left(1 \sigma_{s}, 0.5 \sigma_{s}\right)$, and $\left(0.5 \sigma_{s}, 1 \sigma_{s}\right)$, respectively, where $\sigma_{s}$ represents the daily standard deviation of TAIEX indices. The standard errors are in parentheses. ${ }^{*},{ }^{* *},{ }^{* * *}$ denote significance levels at $10 \%, 5 \%$ and $1 \%$, respectively.

(sell) orders than market buy (sell) orders, but reduce limit sell (buy) orders rather than market sell (buy) orders. The decrease in limit sell (buy) orders exceeds the increase in limit buy (sell) orders, thus establishing a negative relationship between transient volatility and the subsequent increment of market depth found in Table 4 for bear markets. In bull markets, liquidity traders increase their limit buy and limit sell orders in response to increased upside transient volatility, but do not take significant limit order submission in response to downside transient volatility. Therefore, in bull markets, liquidity traders are much more willing to provide liquidity once the 
price-driven volatility occurs at higher prices (ask price). The positive autocorrelation of market depth on the buy and sell sides indicates order persistence.

The above findings demonstrate that market conditions influence the limit order submission behavior of liquidity traders. In bull markets, increased transient volatility drives increased subsequent market depth. Conversely, in bear markets, increased transient volatility decreases subsequent market depth. Additionally, limit orders on the buy and sell sides are positively affected by upside transient volatility in bull markets while limit orders on the buy and sell sides are positively affected by transient volatility on the buy and sell sides, respectively, in bear markets.

\section{(iii) Impact of Market Depth on Subsequent Transient Volatility}

Table 6 lists the estimation results regarding the influence of market depth on subsequent transient volatility. The relationship between market depth and subsequent transient volatility is significantly positive in bull markets, which contradicts the findings of Ahn et al. (2001) who find a negative relationship between market depth and subsequent transient volatility. This study also reveals a positive relationship between transaction volume and transient volatility in bull markets. That is, trading activity in a bull market is much more intensive than in a bear market. Accordingly, liquidity traders using limit orders are more likely to gain from trading against other liquidity traders in bull markets.

Table 7 lists the estimation results for the relationships among upside (downside) volatility, bid depth and ask depth. For market depth, as measured by limit order size, no significant relationships are noted between upside (downside) volatility, bid depth and ask depth during bull and bear markets. However, during bull markets, trading volume is positively related to upside (downside) volatility. These analytical results are consistent with the findings of past studies that price volatility is provoked by trading flows as information is rapidly diffused through intensive trading (e.g., Kyle, 1985: Admati and Pfleiderer, 1988; Foster and Viswanathan, 1990; and Holden and Subrahmanyam, 1992).

Market depth, measured by the number of limit orders, reveals a positive relationship between upside risk and bid depth in bull markets. Additionally, in bull markets, the downside risk is significantly and positively related to bid depth, but significantly and negatively related to ask depth. Coupled with the findings in Table 6 , this indicates that, during bull markets, price volatility is more sensitive to limit orders on the buy side. Therefore, the positive relationship between market depth and subsequent transient volatility in bull markets shown in Table 6 is caused by bid depth. This shows that market orders tend to flow into the market when liquidity traders submit more buy orders, which increases subsequent risk. Consequently, in bull markets, liquidity traders are more aggressive, especially on the bid side.

\section{(iv) Influence of Institutional Trading on Liquidity Provision Behavior}

To clarify whether institutional trading induces the asymmetric liquidity provision during bull and bear markets, sample data were partitioned into high and low institutional trading days using the median ratio of institutional trading volume to total trading volume in a day. Table 8 shows descriptive statistics for high and low institutional trading subsamples. Average cumulative return is positive for higher institutional trading days, while average cumulative return is negative for lower 
Table 6

Regression of Subsequent Transitory Volatility on Market Depth

\begin{tabular}{|c|c|c|c|c|c|c|}
\hline & \multicolumn{3}{|c|}{$\begin{array}{l}\text { Limit Order Sizes } \\
\left(\text { DEPTHVOL }_{t-1}\right)\end{array}$} & \multicolumn{3}{|c|}{$\begin{array}{l}\text { Number of Limit Orders } \\
\left(\text { DEPTHORD }_{t-1}\right)\end{array}$} \\
\hline & $\beta_{1}$ & $\beta_{2}$ & $\beta_{3}$ & $\gamma_{1}$ & $\gamma_{2}$ & $\gamma_{3}$ \\
\hline \multirow[t]{2}{*}{$\begin{array}{l}\text { Whole } \\
\text { Period }\end{array}$} & $33.0180^{*}$ & $0.0858^{* * *}$ & $0.0002^{*}$ & $31.2610^{*}$ & $0.0961^{* * *}$ & $0.0008^{* * *}$ \\
\hline & (18.9820) & $(0.0335)$ & $(0.0001)$ & $(18.2060)$ & $(0.0320)$ & $(0.0003)$ \\
\hline 2002 & $\begin{array}{c}42.6180 \\
(33.1230)\end{array}$ & $\begin{array}{l}0.1680^{* * *} \\
(0.0384)\end{array}$ & $\begin{array}{l}0.0002^{* *} \\
(0.0001)\end{array}$ & $\begin{array}{c}41.3040 \\
(31.9520)\end{array}$ & $\begin{array}{l}0.1510^{* * *} \\
(0.0314)\end{array}$ & $\begin{array}{c}0.0002 \\
(0.0001)\end{array}$ \\
\hline 2003 & $\begin{array}{c}13.4360 \\
(13.1200)\end{array}$ & $\begin{array}{r}0.0909^{*} \\
(0.0514)\end{array}$ & $\begin{array}{l}-0.0146 \\
(0.0094)\end{array}$ & $\begin{array}{c}14.0040 \\
(12.6710)\end{array}$ & $\begin{array}{l}0.1000^{* *} \\
(0.0485)\end{array}$ & $\begin{array}{c}0.0131 \\
(0.0090)\end{array}$ \\
\hline \multicolumn{7}{|l|}{ BB1 } \\
\hline Bear1 & $\begin{array}{c}14.7550 \\
(17.2610)\end{array}$ & $\begin{array}{c}0.1300 \\
(0.0810)\end{array}$ & $\begin{array}{r}-0.0120 \\
(0.0098)\end{array}$ & $\begin{array}{c}14.5390 \\
(15.3880)\end{array}$ & $\begin{array}{r}0.1300^{*} \\
(0.0686)\end{array}$ & $\begin{array}{r}0.0043^{*} \\
(0.0025)\end{array}$ \\
\hline Bull1 & $\begin{array}{c}50.3450 \\
(40.4430)\end{array}$ & $\begin{array}{l}0.0606^{* * *} \\
(0.0155)\end{array}$ & $\begin{array}{l}0.0003^{* * *} \\
(0.0001)\end{array}$ & $\begin{array}{c}48.3590 \\
(39.0530)\end{array}$ & $\begin{array}{l}0.0744^{* * *} \\
(0.0174)\end{array}$ & $\begin{array}{l}0.0008^{* * *} \\
(0.0002)\end{array}$ \\
\hline \multicolumn{7}{|l|}{ BB2 } \\
\hline Bear2 & $\begin{array}{c}15.8730 \\
(17.2760)\end{array}$ & $\begin{array}{c}0.1240 \\
(0.0780)\end{array}$ & $\begin{array}{r}-0.0120 \\
(0.0095)\end{array}$ & $\begin{array}{c}15.7800 \\
(15.5410)\end{array}$ & $\begin{array}{c}0.1250^{*} \\
(0.0663)\end{array}$ & $\begin{array}{c}0.0052^{* *} \\
(0.0026)\end{array}$ \\
\hline Bull2 & $\begin{array}{c}49.4970 \\
(40.0690)\end{array}$ & $\begin{array}{l}0.0632^{* * *} \\
(0.0160)\end{array}$ & $\begin{array}{l}0.0003^{* * *} \\
(0.0001)\end{array}$ & $\begin{array}{c}47.3750 \\
(38.5950)\end{array}$ & $\begin{array}{l}0.0776^{* * *} \\
(0.0179)\end{array}$ & $\begin{array}{l}0.0008^{* * *} \\
(0.0002)\end{array}$ \\
\hline \multicolumn{7}{|l|}{ BB3 } \\
\hline Bear3 & $\begin{array}{c}17.8060 \\
(17.2880)\end{array}$ & $\begin{array}{c}0.1140 \\
(0.0713)\end{array}$ & $\begin{array}{r}-0.0097 \\
(0.0085)\end{array}$ & $\begin{array}{c}17.2620 \\
(15.7470)\end{array}$ & $\begin{array}{r}0.1180^{*} \\
(0.0616)\end{array}$ & $\begin{array}{l}0.0056^{* * *} \\
(0.0023)\end{array}$ \\
\hline Bull3 & $\begin{array}{c}47.8230 \\
(39.6410)\end{array}$ & $\begin{array}{l}0.0666^{* * *} \\
(0.0171)\end{array}$ & $\begin{array}{l}0.0003^{* * *} \\
(0.0001)\end{array}$ & $\begin{array}{c}45.7960 \\
(38.2020)\end{array}$ & $\begin{array}{l}0.0804^{* * *} \\
(0.0189)\end{array}$ & $\begin{array}{l}0.0008^{* * *} \\
(0.0002)\end{array}$ \\
\hline \multicolumn{7}{|l|}{ BB4 } \\
\hline Bear4 & $\begin{array}{c}14.0620 \\
(17.1990)\end{array}$ & $\begin{array}{c}0.1330 \\
(0.0845)\end{array}$ & $\begin{array}{r}-0.0122 \\
(0.0098)\end{array}$ & $\begin{array}{c}14.0130 \\
(15.3130)\end{array}$ & $\begin{array}{c}0.1320^{*} \\
(0.0722)\end{array}$ & $\begin{array}{c}0.0046^{*} \\
(0.0027)\end{array}$ \\
\hline Bull4 & $\begin{array}{c}50.9930 \\
(40.5640)\end{array}$ & $\begin{array}{l}0.0610^{\text {*** }} \\
(0.0150)\end{array}$ & $\begin{array}{l}0.0003^{\text {**** }} \\
(0.0001)\end{array}$ & $\begin{array}{c}48.9030 \\
(39.1250)\end{array}$ & $\begin{array}{l}0.0748^{* * *} \\
(0.0169)\end{array}$ & $\begin{array}{c}0.0008^{\text {*** }} \\
(0.0002)\end{array}$ \\
\hline
\end{tabular}

Notes:

The sample period runs from January 1, 2002 to December 31, 2003, and comprises 497 trading days. This table shows the GMM estimates of regression models based on 15-minute intervals and adjusted for serial correlation by Newey and West (1987). The regression models are:

$$
\begin{gathered}
\operatorname{RISK}_{t}=\alpha_{1}+\beta_{1} \operatorname{RISK}_{t-1}+\beta_{2} \operatorname{VOLUME}_{t}+\beta_{3} \operatorname{DEPTHVOL}_{t-1}+\sum_{i=1}^{18} \rho_{i} \operatorname{TIME}_{i, t}+\varepsilon_{1 t} \\
\operatorname{RISK}_{t}=\alpha_{1}+\gamma_{1} \operatorname{RISK}_{t-1}+\gamma_{2} \operatorname{NTRADEORD}_{t}+\gamma_{3} \operatorname{DEPTHORD}_{t-1}+\sum_{i 1}^{18} \rho_{i} \mathrm{TIME}_{i, t}+\varepsilon_{2 t}
\end{gathered}
$$

where $\mathrm{RISK}_{t}$ represents the volatility measured as the sum of the squared returns during time interval $t$;

DEPTHVOL $_{t-1}\left(\right.$ DEPTHORD $_{t-1}$ ), is thepth (total size (number $\phi$ f outstanding limit orders at the bid

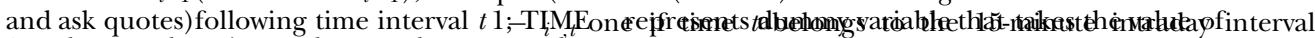
$i$, and zero otherwise; and $\varepsilon_{1 t}$ and $\varepsilon_{2 t}$ are random error terms. Moreover, BB1, BB2, BB3 and BB4 represent the $\left(\lambda_{1}, \lambda_{2}\right)$ values of $\left(1 \sigma_{s}, 1 \sigma_{s}\right),\left(0.5 \sigma_{s}, 0.5 \sigma_{s}\right)$, $\left(1 \sigma_{s}, 0.5 \sigma_{s}\right)$ and $\left(0.5 \sigma_{s}, 1 \sigma_{s}\right)$, respectively, where $\sigma_{s}$ represents the daily standard deviation of TAIEX indices. Reported coefficients and standard errors are magnified by $10^{3}$ for the exposition purpose. The standard errors are in parentheses. ${ }^{*},{ }^{* *},{ }^{* * *}$ denote the significance levels at $10 \%, 5 \%$ and $1 \%$, respectively.

institutional trading days. Further, average trading volume, average order imbalance by size and by number of orders and the number of trades are larger for more active institutional trading days than for less active institutional trading days. However, the average spread and average percentage spread are higher for low institutional trading 


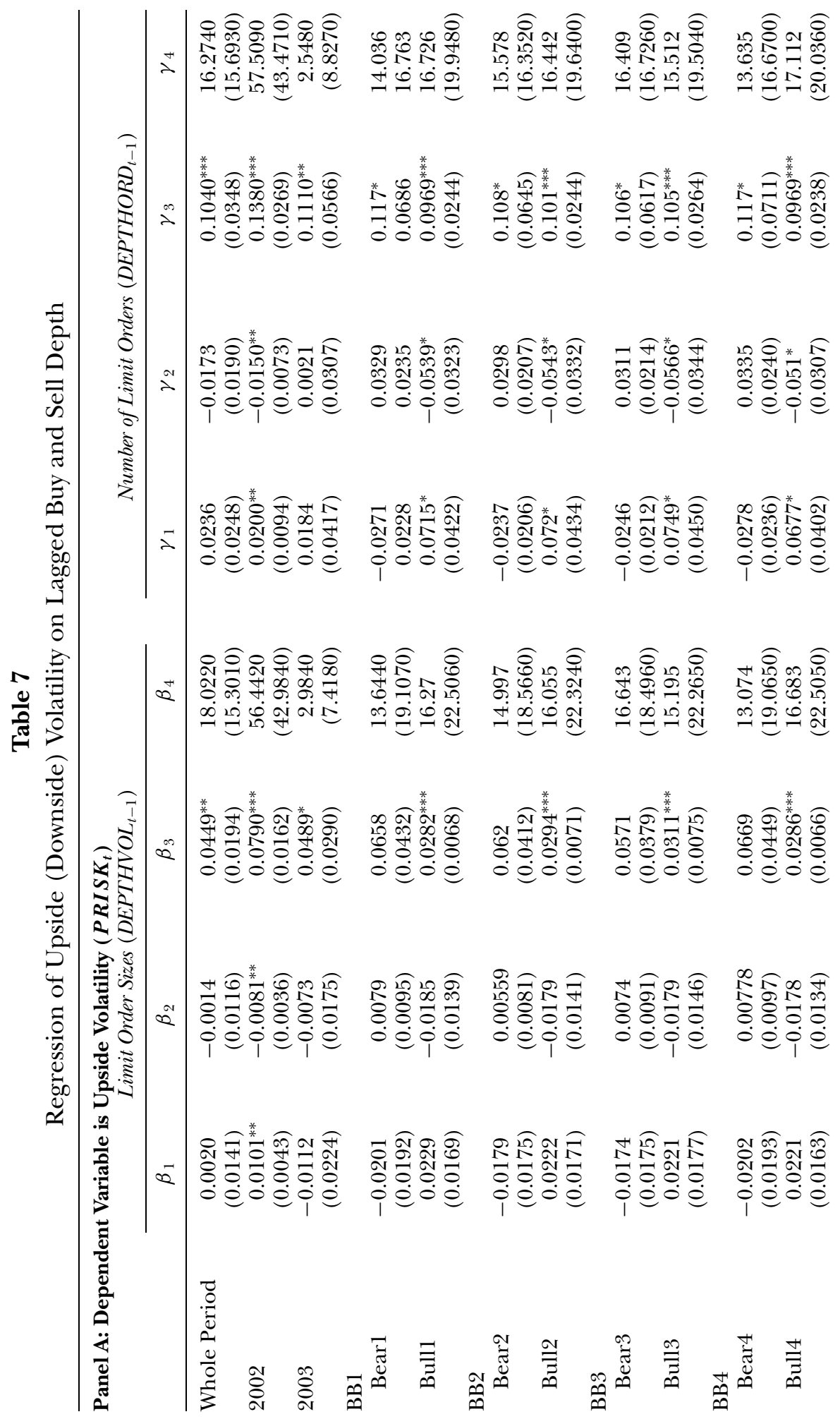




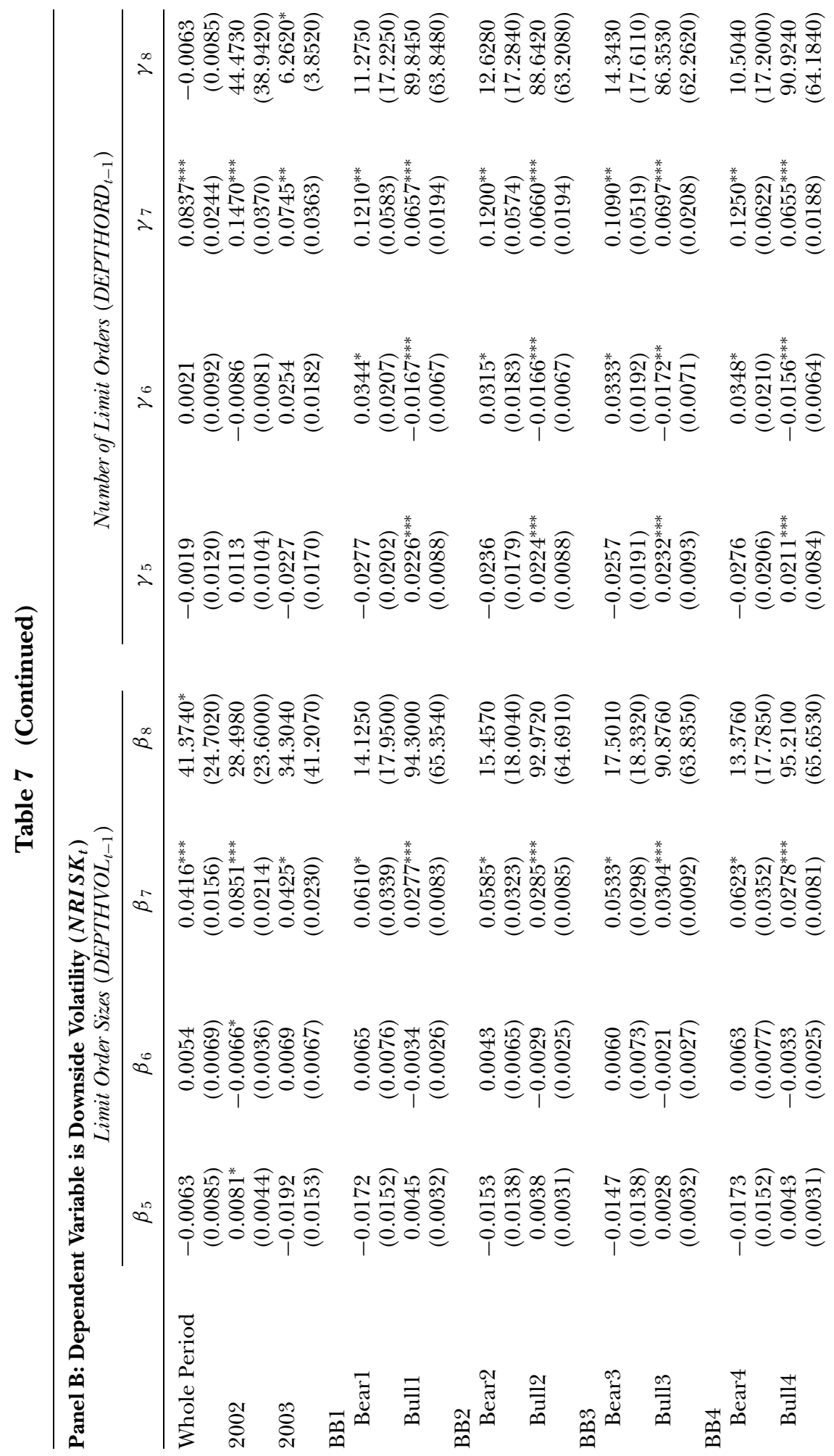




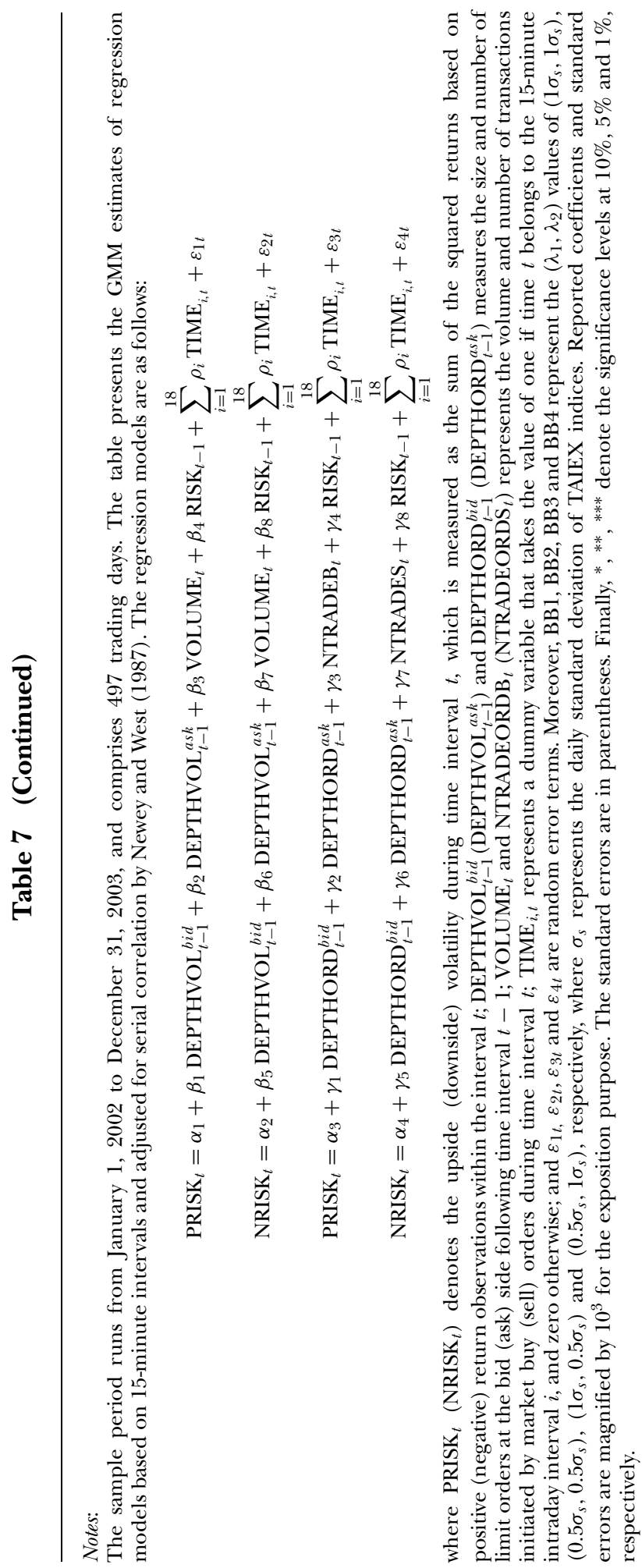


Table 8

Descriptive Statistics of Institutional Trading for TAIFEX from 2002 to 2003

\begin{tabular}{|c|c|c|c|c|c|c|c|c|c|}
\hline Variable & Price & Spread & $\begin{array}{c}\text { Spread } \\
(\%)\end{array}$ & Return & $\begin{array}{l}\text { No. of } \\
\text { Trades }\end{array}$ & Volume & Imb_Order & $I m b_{-} V o l$ & Inst_Ratio \\
\hline \multicolumn{10}{|c|}{ Panel A: Low Institutional Trading } \\
\hline Mean & $5,249^{* *}$ & $2.566^{* * *}$ & $0.012^{* * *}$ & -0.001 & 9,362 & $16,521^{* * *}$ & $0.004^{*}$ & 0.002 & $0.090^{* * *}$ \\
\hline Std Dev & 636 & 1.590 & 0.007 & 0.072 & 4,517 & 8,633 & 0.048 & 0.033 & 0.020 \\
\hline Min & 3,859 & 1.235 & 0.005 & -0.174 & 212 & 259 & -0.342 & -0.138 & 0.040 \\
\hline Median & 5,320 & 2.218 & 0.011 & 0.004 & 9,039 & 15,984 & 0.007 & 0.001 & 0.091 \\
\hline Max & 6,390 & 14.066 & 0.061 & 0.212 & 23,402 & 46,382 & 0.196 & 0.158 & 0.122 \\
\hline \multirow[t]{2}{*}{ Obs } & 247 & 247 & 247 & 247 & 247 & 247 & 247 & 247 & 247 \\
\hline & $(54.6)$ & $(54.6)$ & $(54.6)$ & $(54.6)$ & $(54.6)$ & $(54.6)$ & $(54.6)$ & $(54.6)$ & $(54.6)$ \\
\hline \multicolumn{10}{|c|}{ Panel B: High Institutional Trading } \\
\hline Mean & 5,124 & 1.879 & 0.009 & 0.011 & 9,976 & 18,972 & 0.015 & 0.004 & 0.176 \\
\hline Std Dev & 648 & 0.712 & 0.004 & 0.065 & 5,120 & 10,854 & 0.063 & 0.034 & 0.056 \\
\hline Min & 3,853 & 1.236 & 0.005 & -0.163 & 439 & 582 & -0.175 & -0.113 & 0.122 \\
\hline Median & 5,001 & 1.669 & 0.009 & 0.013 & 9,899 & 18,443 & 0.010 & 0.001 & 0.161 \\
\hline Max & 6,338 & 5.988 & 0.031 & 0.207 & 23,390 & 46,576 & 0.185 & 0.153 & 0.468 \\
\hline \multirow[t]{2}{*}{ Obs } & 245 & 245 & 245 & 245 & 245 & 245 & 245 & 245 & 245 \\
\hline & $(45.4)$ & $(45.4)$ & $(45.4)$ & $(45.4)$ & $(45.4)$ & $(45.4)$ & $(45.4)$ & $(45.4)$ & $(45.4)$ \\
\hline
\end{tabular}

Notes:

The sample period runs from January 1, 2002 to December 31, 2003, and comprises 492 trading days. High and low institutional trading days are classified according to the medium of Inst_ratio of entire data. Price is the daily price in index points for the most actively traded future contracts. Moreover, spread indicates the daily difference between the best bid and ask prices in index points. Furthermore, spread percentage is the daily percentage of the spread divided by the midpoint of the best bid and ask prices. Return is the cumulative daily return of Taiwan Stock Exchange Capitalization Weighted Index from $t-$ 20 to $t-1$. Number of trades is the daily number of trades for the most actively traded futures contracts. Volume represents the average daily volume of trades for the most actively traded futures contracts. Imb_order is the daily difference between number of buy and number of sell limit orders divided by the daily sum of number of buy and sell limit orders. Imb_vol is the daily difference between the buy and sell limit order sizes divided by the sum of daily buy and sell limit sizes. Finally, Inst_ratio represents the ratio of daily institutional trading volume to the daily trading volume. The ratios in parentheses show percentages of observations classified to the whole sample. Mann-Whitney-Wilcoxon tests are performed for the differences between all variables in 2002 and 2003. *,**,** denote significance levels at $10 \%, 5 \%$ and $1 \%$, respectively.

days. Therefore, institutional traders trade actively on days when trading costs are lower.

Table 9 reveals the relationship between transient volatility and subsequent market depth for institutional trading activity. Panel A of Table 9 shows the estimation results for lower institutional trading. The transient volatility is significantly and positively related to subsequent market depth in both bull and bear markets. Therefore, increased liquidity trading causes liquidity traders to submit more orders when transient volatility is higher.

The estimation results for high institutional trading in Panel B of Table 9 show that higher institutional trading induces a negative relationship between transient volatility and subsequent market depth during bear markets. Hence, this empirical evidence is consistent with the findings in Table 3 that liquidity traders do not trade actively during bear markets with active institutional trading, since the probability of trading against informed institutional traders is higher when institutional trading is much more intensive.

Table 10 presents the estimation results for the relationsh ip between mark et depth and subsequent transient volatility for institutional trading. The estimation results 


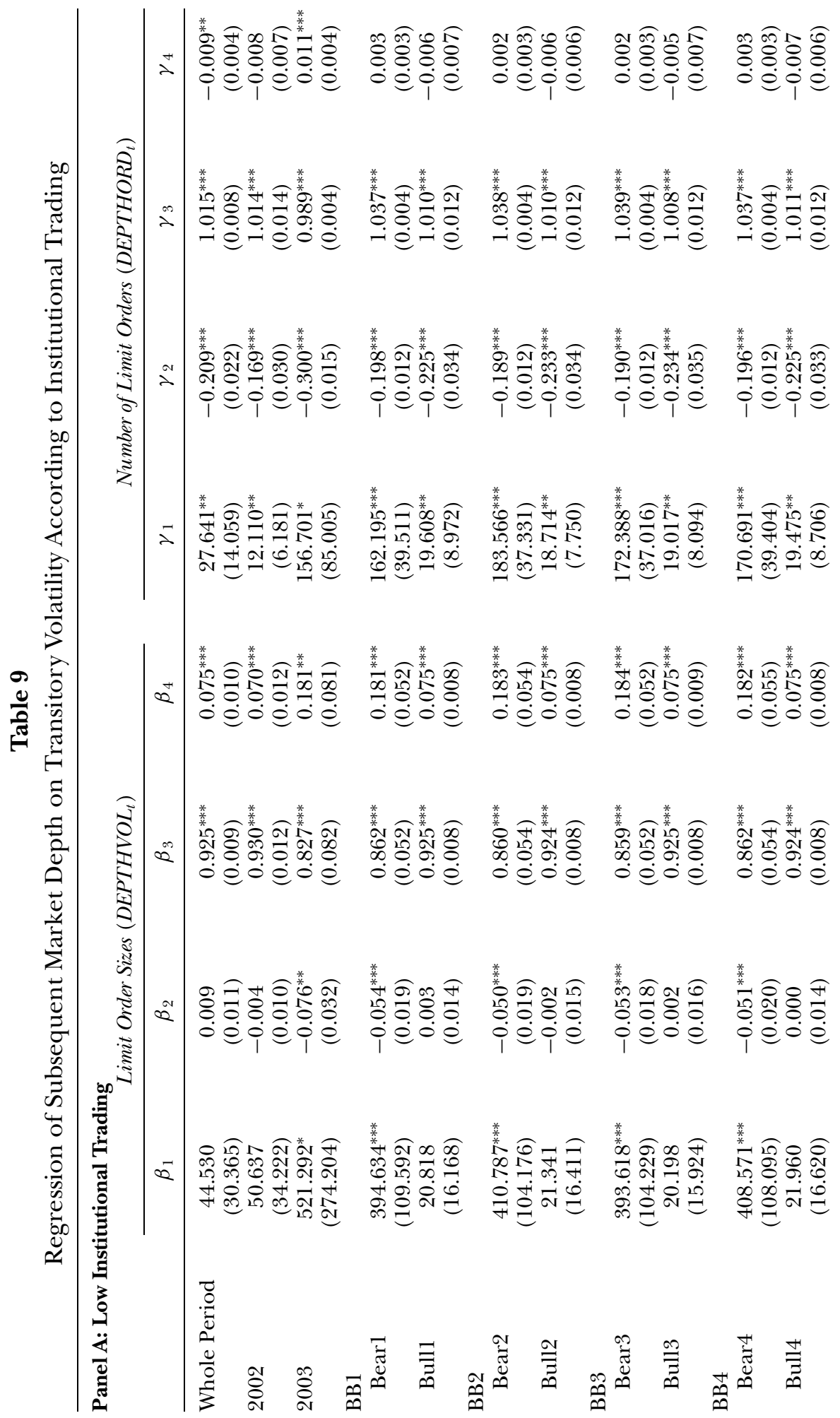




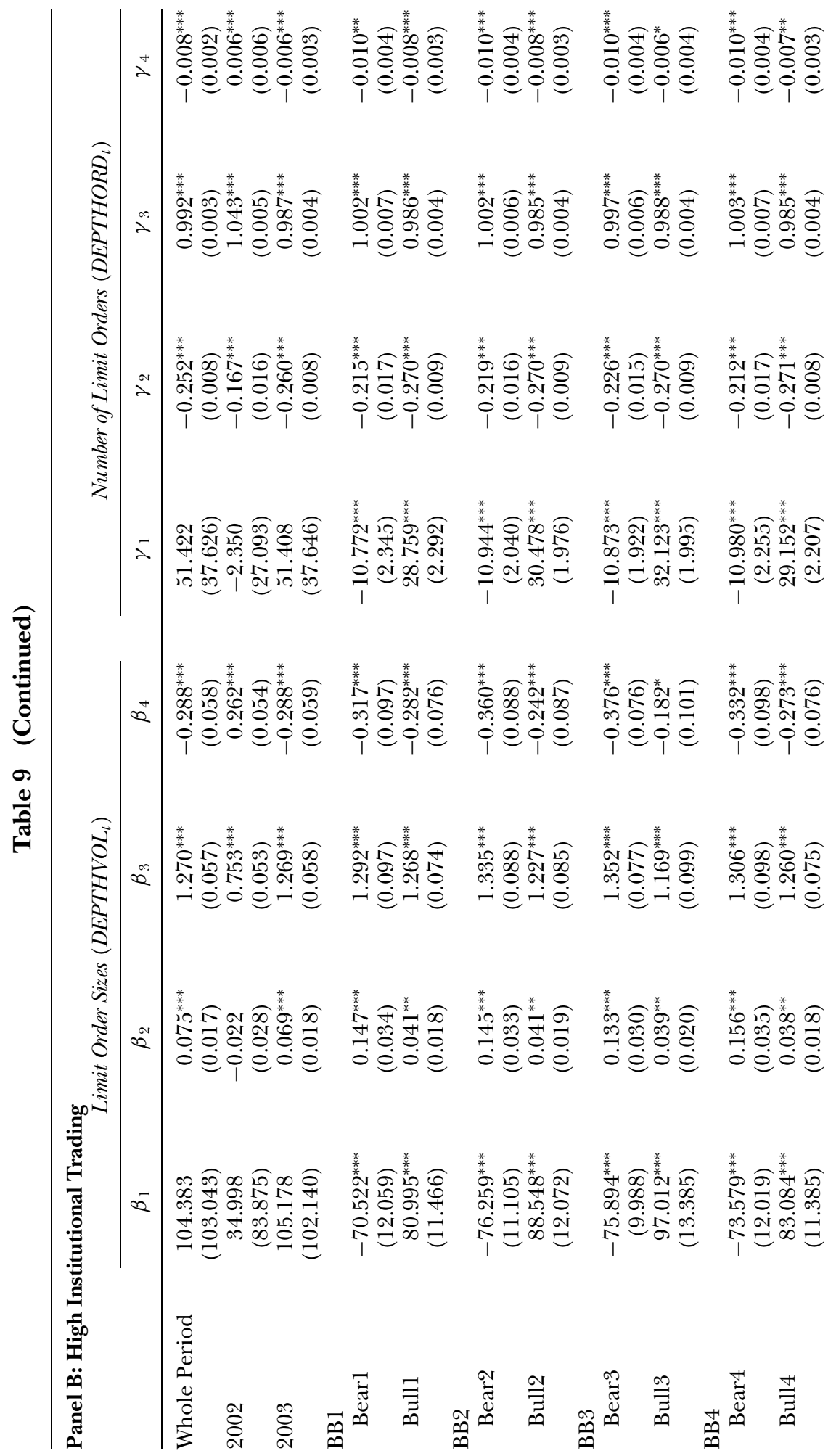




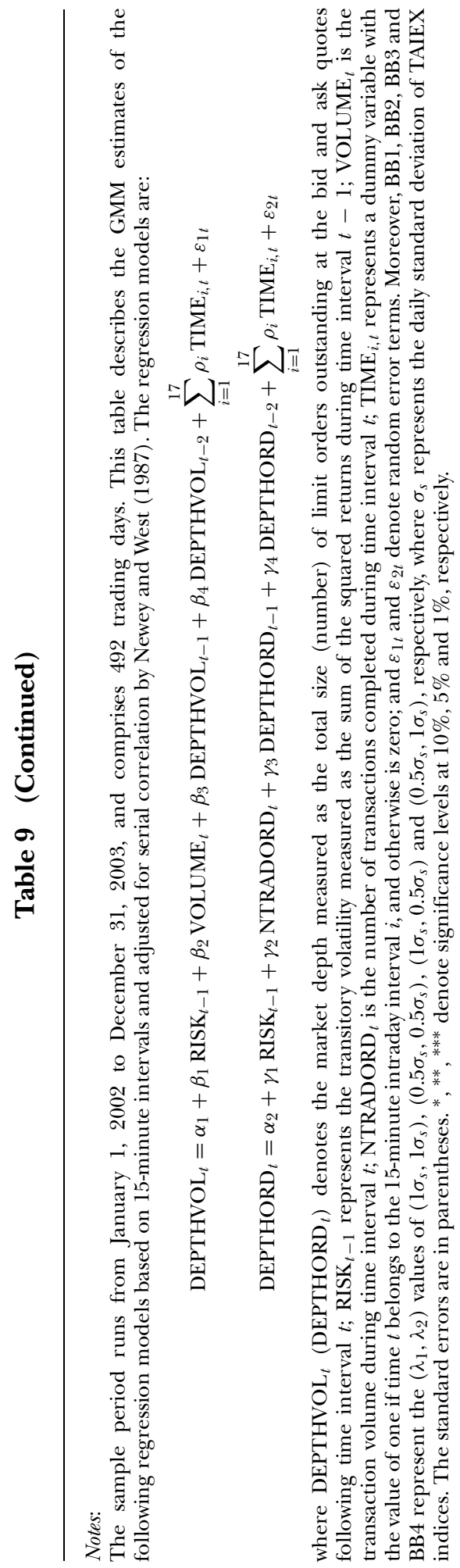


Table 10

Regression of Subsequent Transitory Volatility on Market Depth According to Institutional Trading

\begin{tabular}{|c|c|c|c|c|c|c|}
\hline & \multicolumn{3}{|c|}{$\begin{array}{l}\text { Limit Order Sizes } \\
\left(\text { DEPTHVOL }_{t-1}\right)\end{array}$} & \multicolumn{3}{|c|}{$\begin{array}{l}\text { Number of Limit Orders } \\
\left(\text { DEPTHORD }_{t-1}\right)\end{array}$} \\
\hline & $\beta_{1}$ & $\beta_{2}$ & $\beta_{3}$ & $\gamma_{1}$ & $\gamma_{2}$ & $\gamma_{3}$ \\
\hline \multicolumn{7}{|c|}{ Panel A: Low Institutional trading } \\
\hline $\begin{array}{l}\text { Whole } \\
\text { Period }\end{array}$ & 46.9330 & $0.0865^{* * *}$ & $0.0002^{* * *}$ & 44.5600 & $0.0942^{* * *}$ & $0.0005^{* * *}$ \\
\hline & $(35.1670)$ & $(0.0233)$ & $(0.0001)$ & $(33.5040)$ & $(0.0227)$ & $(0.0001)$ \\
\hline 2002 & $\begin{array}{c}34.3110 \\
(28.4080)\end{array}$ & $\begin{array}{l}0.1770^{* * *} \\
(0.0439)\end{array}$ & $\begin{array}{l}0.0002^{* *} \\
(0.0001)\end{array}$ & $\begin{array}{c}33.2330 \\
(27.3600)\end{array}$ & $\begin{array}{l}0.1590^{* * * *} \\
(0.0360)\end{array}$ & $\begin{array}{l}0.0002 \\
(0.0001)\end{array}$ \\
\hline 2003 & $\begin{array}{l}215.5990^{* * *} \\
(53.4210)\end{array}$ & $\begin{array}{l}0.0436^{* * *} \\
(0.0065)\end{array}$ & $\begin{array}{l}-0.0068^{* * *} \\
(0.0020)\end{array}$ & $\begin{array}{l}220.7780^{* * *} \\
(55.3270)\end{array}$ & $\begin{array}{l}0.0392^{* * *} \\
(0.0065)\end{array}$ & $\begin{array}{r}-0.0026^{*} \\
(0.0014)\end{array}$ \\
\hline \multicolumn{7}{|l|}{ BB1 } \\
\hline Bear1 & $\begin{array}{c}19.5680 \\
(19.4580)\end{array}$ & $\begin{array}{l}0.0613^{* * *} \\
(0.0086)\end{array}$ & $\begin{array}{r}-0.0036 \\
(0.0029)\end{array}$ & $\begin{array}{c}18.5000 \\
(18.3220)\end{array}$ & $\begin{array}{l}0.0663^{* * *} \\
(0.0104)\end{array}$ & $\begin{array}{c}0.0012 \\
(0.0029)\end{array}$ \\
\hline Bull1 & $\begin{array}{l}102.7470 \\
(78.8370)\end{array}$ & $\begin{array}{l}0.1100^{* * *} \\
(0.0426)\end{array}$ & $\begin{array}{l}0.0002^{* *} \\
(0.0001)\end{array}$ & $\begin{array}{c}97.7750 \\
(76.2740)\end{array}$ & $\begin{array}{l}0.1150^{* * *} \\
(0.0405)\end{array}$ & $\begin{array}{l}0.0004^{* * *} \\
(0.0002)\end{array}$ \\
\hline \multicolumn{7}{|l|}{ BB2 } \\
\hline Bear2 & $\begin{array}{l}19.7580 \\
(19.7490)\end{array}$ & $\begin{array}{l}0.0605^{* * *} \\
(0.0088)\end{array}$ & $\begin{array}{r}-0.0044 \\
(0.0030)\end{array}$ & $\begin{array}{c}18.7540 \\
(18.7160)\end{array}$ & $\begin{array}{l}0.0654^{* * *} \\
(0.0104)\end{array}$ & $\begin{array}{c}0.0029 \\
(0.0030)\end{array}$ \\
\hline Bull2 & $\begin{array}{l}101.6630 \\
(78.4580)\end{array}$ & $\begin{array}{l}0.1130^{* * *} \\
(0.0436)\end{array}$ & $\begin{array}{l}0.0002^{* * *} \\
(0.0001)\end{array}$ & $\begin{array}{c}96.4100 \\
(75.7720)\end{array}$ & $\begin{array}{l}0.1180^{* * *} \\
(0.0414)\end{array}$ & $\begin{array}{l}0.0004^{* * *} \\
(0.0001)\end{array}$ \\
\hline \multicolumn{7}{|l|}{ BB3 } \\
\hline Bear3 & $\begin{array}{l}20.5160 \\
(20.2840)\end{array}$ & $\begin{array}{l}0.0613^{* * *} \\
(0.0083)\end{array}$ & $\begin{array}{r}-0.0042 \\
(0.0030)\end{array}$ & $\begin{array}{l}19.4320 \\
(19.1670)\end{array}$ & $\begin{array}{l}0.0661^{* * *} \\
(0.0098)\end{array}$ & $\begin{array}{c}0.0021 \\
(0.0028)\end{array}$ \\
\hline Bull3 & $\begin{array}{l}100.3580 \\
(78.1180)\end{array}$ & $\begin{array}{l}0.1150^{* * *} \\
(0.0454)\end{array}$ & $\begin{array}{l}0.0002^{* *} \\
(0.0001)\end{array}$ & $\begin{array}{c}95.3450 \\
(75.5140)\end{array}$ & $\begin{array}{l}0.1190^{* * *} \\
(0.0429)\end{array}$ & $\begin{array}{l}0.0004^{* *} \\
(0.0002)\end{array}$ \\
\hline \multicolumn{7}{|l|}{ BB4 } \\
\hline Bear4 & $\begin{array}{c}19.0430 \\
(19.0880)\end{array}$ & $\begin{array}{l}0.0608^{* * *} \\
(0.0091)\end{array}$ & $\begin{array}{r}-0.0038 \\
(0.0030)\end{array}$ & $\begin{array}{c}18.0470 \\
(18.0260)\end{array}$ & $\begin{array}{l}0.0658^{* * *} \\
(0.0110)\end{array}$ & $\begin{array}{c}0.0017 \\
(0.0031)\end{array}$ \\
\hline Bull4 & $\begin{array}{l}103.6110 \\
(78.9890)\end{array}$ & $\begin{array}{l}0.1090^{* * *} \\
(0.0411)\end{array}$ & $\begin{array}{l}0.0002^{* * *} \\
(0.0001)\end{array}$ & $\begin{array}{c}98.4680 \\
(76.3700)\end{array}$ & $\begin{array}{c}0.1140^{* * *} \\
(0.0392)\end{array}$ & $\begin{array}{l}0.0004^{* * *} \\
(0.0001)\end{array}$ \\
\hline
\end{tabular}

\begin{tabular}{ccccccc}
\hline $\begin{array}{l}\text { Panel B: High Institutional Trading } \\
\text { Whole }\end{array}$ & 19.5410 & $0.0990^{*}$ & -0.0159 & 19.1160 & $0.1160^{* *}$ & $0.0173^{* *}$ \\
Period & & & & & & \\
& $(18.9640)$ & $(0.0596)$ & $(0.0113)$ & $(18.3650)$ & $(0.0566)$ & $(0.0086)$ \\
2002 & $364.0990^{* * *}$ & $0.1370^{* * *}$ & $-0.0291^{* * *}$ & $360.7220^{* * *}$ & $0.0903^{* * *}$ & 0.0041 \\
& $(118.9190)$ & $(0.0249)$ & $(0.0076)$ & $(119.4500)$ & $(0.0218)$ & $(0.0051)$ \\
2003 & 11.4340 & $0.1020^{*}$ & -0.0147 & 11.2430 & $0.1200^{* *}$ & $0.0177^{*}$ \\
& $(13.3940)$ & $(0.0624)$ & $(0.0112)$ & $(12.9950)$ & $(0.0610)$ & $(0.0108)$ \\
BB1 & & & & & & \\
Bear1 & 2.5770 & 0.1820 & -0.0228 & 5.3750 & 0.1800 & 0.0048 \\
& $(31.6130)$ & $(0.1350)$ & $(0.0177)$ & $(28.2500)$ & $(0.1250)$ & $(0.0039)$ \\
Bull1 & 22.1140 & $0.0405^{* * *}$ & -0.0065 & 25.0870 & $0.0749^{* * *}$ & 0.0255 \\
& $(29.0550)$ & $(0.0091)$ & $(0.0072)$ & $(27.1830)$ & $(0.0249)$ & $(0.0168)$ \\
BB2 & & & & & & \\
Bear2 & 4.8360 & 0.1730 & -0.0209 & 7.3080 & 0.1720 & 0.0039 \\
& $(31.1180)$ & $(0.1290)$ & $(0.0161)$ & $(28.1510)$ & $(0.1200)$ & $(0.0040)$ \\
Bull2 & 21.3290 & $0.0420^{* * *}$ & -0.0066 & 24.2730 & $0.0782^{* * *}$ & 0.0264 \\
& $(28.9480)$ & $(0.0100)$ & $(0.0072)$ & $(26.9620)$ & $(0.0265)$ & $(0.0171)$
\end{tabular}


Table 10 (Continued)

\begin{tabular}{cccccccc}
\hline & \multicolumn{3}{c}{$\begin{array}{c}\text { Limit Order Sizes } \\
(\text { DEPTHVOL }\end{array}$-1 $)$} & & & \multicolumn{3}{c}{$\begin{array}{c}\text { Number of Limit Orders } \\
\left(\text { DEPTHORD }_{t-1}\right)\end{array}$} \\
& $\beta_{1}$ & $\beta_{2}$ & $\beta_{3}$ & & $\gamma_{1}$ & $\gamma_{2}$ & $\gamma_{3}$ \\
\hline BB3 & & & & & & \\
Bear3 & 8.8270 & 0.1520 & -0.0164 & 10.3470 & 0.1570 & 0.0047 \\
& $(29.9880)$ & $(0.1150)$ & $(0.0137)$ & $(27.5250)$ & $(0.1100)$ & $(0.0037)$ \\
Bull3 & 20.4170 & $0.0491^{* * *}$ & -0.0106 & 23.1200 & $0.0833^{* * *}$ & 0.0275 \\
& $(28.8560)$ & $(0.0120)$ & $(0.0085)$ & $(26.8710)$ & $(0.0285)$ & $(0.0180)$ \\
BB4 & & & & & & \\
Bear4 & 1.6710 & 0.1870 & -0.0224 & & 4.6050 & 0.1860 & 0.0050 \\
& $(31.8720)$ & $(0.1400)$ & $(0.0170)$ & $(28.5840)$ & $(0.1320)$ & $(0.0042)$ \\
Bull4 & 22.5610 & $0.0413^{* * *}$ & -0.0061 & 25.4010 & $0.0748^{* * *}$ & 0.0245 \\
& $(29.1310)$ & $(0.0093)$ & $(0.0070)$ & $(27.2970)$ & $(0.0245)$ & $(0.0161)$ \\
\hline
\end{tabular}

Notes:

The sample period runs from January 1, 2002 to December 31, 2003, and comprises 492 trading days. This table shows the GMM estimates of regression models based on 15-minute intervals and adjusted for serial correlation by Newey and West (1987). The regression models are:

$$
\begin{aligned}
& \operatorname{RISK}_{t}=\alpha_{1}+\beta_{1} \mathrm{RISK}_{t-1}+\beta_{2} \operatorname{VOLUME}_{t}+\beta_{3} \text { DEPTHVOL }_{t-1}+\sum_{i=1}^{18} \rho_{i} \operatorname{TIME}_{i, t}+\varepsilon_{1 t} \\
& \operatorname{RISK}_{t}=\alpha_{1}+\gamma_{1} \operatorname{RISK}_{t-1}+\gamma_{2} \operatorname{NTRADEORD~}_{t}+\gamma_{3} \text { DEPTHORD }_{t-1}+\sum_{i=1}^{18} \rho_{i} \operatorname{TIME}_{i, t}+\varepsilon_{2 t}
\end{aligned}
$$

where RISK $_{t}$ represents the volatility measured as the sum of the squared returns during time interval $t$; DEPTHVOL $_{t-1}\left(\right.$ DEPTHORD $\left._{t-1}\right)$, is the depth (total size (number) of outstanding limit orders at the bid and ask quotes) following time interval $t-1 ; \mathrm{TIME}_{i, t}$ represents a dummy variable that takes the value of one if time $t$ belongs to the 15-minute intraday interval $i$, and zero otherwise; and $\varepsilon_{1 t}$ and $\varepsilon_{2 t}$ are random error terms. Moreover, BB1, BB2, BB3 and BB4 represent the $\left(\lambda_{1}, \lambda_{2}\right)$ values of $\left(1 \sigma_{s}, 1 \sigma_{s}\right),\left(0.5 \sigma_{s}, 0.5 \sigma_{s}\right)$, $\left(1 \sigma_{s}, 0.5 \sigma_{s}\right)$ and $\left(0.5 \sigma_{s}, 1 \sigma_{s}\right)$, respectively, where $\sigma_{s}$ represents the daily standard deviation of TAIEX indices. Reported coefficients and standard errors are magnified by $10^{3}$ for the exposition purpose. The standard errors are in parentheses. ${ }^{*}, * *,{ }^{* * *}$ denote the significance levels at $10 \%, 5 \%$ and $1 \%$, respectively.

indicate that higher depth significantly leads to higher subsequent transient volatility in bull markets when institutional trading is low. Therefore, traders are more active in trading in bull markets when the probability of trading against informed institutional traders is lower, which is consistent with those found in Table 6.

The findings here indicate that asymmetric responses between transient volatility and limit order submission during bear and bull markets are associated with the intensity of institutional trading. When institutional traders are active in the market, liquidity traders take back their limit orders due to the increased probability of being picked off and the increased probability of losses more to informed institutional traders, especially in bear markets. The empirical evidence in this study is consistent with Lee et al. (1993) and Kavajecz (1999), indicating that depth is much smaller when informed trading is more likely.

\section{CONCLUSION}

Given that liquidity provision is a long-standing important structural issue for markets, this work studies market depth for futures contracts using limit order data from the Taiwan Stock Exchange Capitalization Weighted Stock Index futures (TAIEX futures) 
traded on the Taiwan Futures Exchange (TAIFEX). The TAIFEX is a purely orderdriven market without designated market makers obliged to maintain a fair and orderly market. The possible asymmetric pattern of the relationship between market depth and transient volatility in bull and bear markets is also considered, since substantial evidence reveals asymmetric responses in capital markets to upward and downward trends. Further, institutional trading plays a very important role in futures trading. The impact of institutional trading on the relationship between transient volatility and market depth was also examined.

The empirical results reveal a significant and positive relationship between transient volatility and subsequent market depth in bull markets, but not in bear markets. Liquidity traders tend to reduce subsequent market depth when transient volatility increases during bear markets. Thus, in bull markets, the present analytical results regarding the relationship between transient volatility and subsequent market depth are consistent with the findings of Handa and Schwartz (1996) and Ahn et al. (2001).

Liquidity increases if upside volatility is higher in bull markets. Further, the trading volume or number of trades affects transient volatility more positively in bull markets than in bear markets. Analytical results thus indicate the importance of distinguishing between market trends as the liquidity provision by limit orders differs between bull and bear markets. Additionally, the asymmetrical transient volatility-market depth during bear and bull markets is strongly related to the degree of institutional trading activity.

\section{REFERENCES}

Admati, A. R. and P. Pfleiderer (1988), 'A Theory of Intraday Patterns: Volume and Price Variability', Review of Financial Studies, Vol. 1, pp. 3-40.

Ahn, H. J., K. H. Bae and K. Chan (2001), 'Limit Orders, Depth, and Volatility: Evidence from the Stock Exchange of Hong Kong', Journal of Finance, Vol. 56, pp. 767-88.

Bessembinder, H. and P. J. Sequin (1993), 'Price Volatility, Trading Volume, and Market Depth: Evidence from Futures Markets', Journal of Financial and Quantitative Analysis, Vol. 28, pp. 21-39.

Biais, B., P. Hillion and C. Spatt (1995), 'An Empirical Analysis of the Limit Order Book and the Order Flow in the Paris Bourse', Journal of Finance, Vol. 50, pp. 1655-89.

Chakravarty, S. (2001), 'Stealth-Trading: Which Traders' Trades Move Stock Prices?', Journal of Financial Economics, Vol. 61, pp. 289-307.

Chung, K. H. and X. Zhao (2004), 'Making a Market with Spreads and Depths', Journal of Business Finance Ẽ Accounting, Vol. 31, pp. 1069-97.

_ B. F. Van Ness and R. A. Van Ness (1999), 'Limit Orders and the Bid-Ask Spread', Journal of Financial Economics, Vol. 53, pp. 255-87.

Daigler, R. T. and M. K. Wiley (1999), 'The Impact of Trader Type on the Futures VolatilityVolume Relation', Journal of Finance, Vol. 54, pp. 2297-316.

Engle, R. F. and V. K. Ng (1993), 'Measuring and Testing the Impact of News on Volatility', Journal of Finance, Vol. 48, pp. 1749-78.

Foster, D. F. and S. Viswanathan (1990), 'A Theory of the Interday Variation in Volume, Variance, and Trading Costs in Securities Markets', Review of Financial Studies, Vol. 3, pp. 593-624.

Foucault, T. (1999), 'Order Flow Composition and Trading Costs in a Dynamic Limit Order Market', Journal of Financial Markets, Vol. 2, pp. 99-134.

French, K. R., G. W. Schwert and R. F. Stambaugh (1987), 'Expected Stock Returns and Volatility', Journal of Financial Economics, Vol. 19, pp. 3-29. 
Glosten, L. R. (1994), 'Is the Electronic Open Limit Order Book Inevitable?', Journal of Finance, Vol. 49, pp. 1127-61.

and P. R. Milgrom (1985), 'Bid, Ask and Transaction Prices in a Specialist Market with Heterogeneously Informed Traders', Journal of Financial Economics, Vol. 14, pp. 71-100.

- R. Jagannathan and D. E. Runkle (1993), 'On the Relation between the Expected Value and the Volatility of Nominal Excess Return on Stocks', Journal of Finance, Vol. 48, pp. 1779-801.

Handa, P. and R. A. Schwartz (1996), 'Limit Order Trading', Journal of Finance, Vol. 51, pp. $1835-61$.

Hasbrouck, J. (1991), 'Measuring the Information Content of Stock Trades', Journal of Finance, Vol. 46, pp. 179-207.

Holden, C. W. and A. Subrahmanyam (1992), 'Long-Lived Private Information and Imperfect Competition', Journal of Finance, Vol. 47, pp. 247-70.

Kavajecz, A. K. (1999), 'A Specialist's Quoted Depth and the Limit Order Book', Journal of Finance, Vol. 54, pp. 747-71.

Koutmos, G. (1998), 'Asymmetries in the Conditional Mean and the Conditional Variance: Evidence from Nine Stock Markets', Journal of Economics and Business, Vol. 50, pp. 277-90.

Kyle, A. S. (1985), 'Continuous Auctions and Insider Trading', Econometrica, Vol. 53, pp. 131535 .

Lee, C. M., B. Mucklow and M. J. Ready (1993), 'Spreads, Depths, and the Impact of Earnings Information: An Intraday Analysis', Review of Financial Studies, Vol. 6, pp. 345-74.

Lin, J. C., G. Sanger and G. G. Booth (1995), 'Trade Size and Components of the Bid-Ask Spread', Review of Financial Studies, Vol. 8, pp. 1153-83.

Lunde, A. and A. Timmermann (2004), 'Duration Dependence in Stock Prices: An Analysis of Bull and Bear Markets', Journal of Business and Economic Statistics, Vol. 22, pp. 253-73.

Nelson, D. (1991), 'Conditional Heteroskedasticity in Asset Returns: A New Approach', Econometrica, Vol. 59, pp. 347-70.

Newey, W. and K. West (1987), 'Hypothesis Testing with Efficient Method of Moments Estimation', International Economic Review, Vol. 28, pp. 777-87.

Parlour, C. A. (1998), 'Price Dynamics in Limit Order Markets', Review of Financial Studies, Vol. 11, pp. 789-816.

Pirrong, C. (1996), 'Market Liquidity and Depth on Computerized and Open Outcry Trading Systems: A Comparison of DTB and LIFFE Bund Contracts', Journal of Futures Markets, Vol. 16, pp. 519-43.

Schwert, G. W. (1989), 'Why Does Stock Market Volatility Change Over Time?', Journal of Finance, Vol. 44, pp. 1115-53.

Seppi, D. J. (1997), 'Liquidity Provision with Limit Orders and a Strategic Specialist', Review of Financial Studies, Vol. 10, pp. 103-50.

Wiley, M. K. and R. T. Daigler (1998), 'Volume Relationships Among Types of Traders in the Financial Futures Markets', Journal of Futures Markets, Vol. 18, pp. 91-113. 